\title{
Monitoramento mensal da linha de costa no Balneário Mostardense - RS entre 2016/2017 utilizando dados de VANT
}

\author{
Monthly monitoring of coastline in Mostardense beach - RS between \\ 2016/2017 using UAV data
}

\author{
Rodrigo Silva Simões ${ }^{a, b}$, Ulisses Rocha de Oliveira ${ }^{c, d}$ \\ a'Laboratório de Geomorfologia e Recursos Hídricos/Laboratório de Oceanografia Geológica - LOG, Universidade Federal do Rio \\ Grande - FURG \\ 'Instituto de Ciências Humanas e Informação - ICHI, Universidade Federal do Rio Grande - FURG \\ brodrigosimoes@furg.br, ${ }^{\mathrm{d}}$ ulisseslicke@yahoo.com.br
}

\begin{abstract}
Resumo
Neste estudo foi realizado um monitoramento mensal, entre junho de 2016 e junho de 2017, da linha de costa e das dunas frontais no balneário Mostardense. Este segmento de costa situa-se no litoral central do Estado do Rio Grande do Sul, localidade que segundo trabalhos anteriores, sofre com a alta mobilidade eólica e com os efeitos do processo de erosão costeira. Este processo move a linha de costa em direção ao continente, sobretudo sob a ação de tempestades, ameaçando as ocupações mais próximas do limite praia-duna. Para a realização deste trabalho foram utilizadas um total de 258 fotografias aéreas obtidas em campo mensalmente a partir de um VANT (DJI ${ }^{\circledR}$ Phantom 3 Professional) para construção de ortofotomosaicos. Adicionalmente foram coletadas fotografias oblíquas (200), além de dados derivados de dois ondógrafos e de uma estação meteorológica, buscando compreender melhor as taxas de mobilidade da linha de costa, fruto da erosão e recomposição das dunas frontais. Os cálculos de variação de linha de costa foram realizados a partir do método do polígono de mudança. Os resultados demonstram a dinâmica da linha de costa, com destaque para um recuo significativo quando da passagem de um evento extremo de ondas do quadrante $\mathrm{S}$ ocorrido em outubro de 2016, onde houve recuo médio de linha de costa de $13,8 \mathrm{~m}$ entre outubro e novembro do mesmo ano. Também foram identificados períodos de recomposição das dunas frontais por ação eólica, sob o domínio de ventos de NE. Porém, durante o monitoramento realizado, não houveram taxas significativas de recomposição se comparadas com as de recuo. Os resultados obtidos também apontam para as potencialidades da utilização da ferramenta VANT em estudos de morfodinâmica costeira, podendo ser utilizado tanto para análises qualitativas (fotografias oblíquas) como para análises quantitativas (fotografias verticais).
\end{abstract}

Palavras-chave: Limite praia-duna; erosão costeira; VANT (drone); método do polígono de mudança; dunas frontais.

\begin{abstract}
In this study a monthly monitoring was carried out between June 2016 and June 2017 of the coastline and frontal dunes in Mostardense beach. This coastal segment are located on the central coast of the State of Rio Grande do Sul, locality which, as demonstrated by previous works, suffers from the high aeolian mobility and the effects of the coastal erosion process. This process moves the coastline towards inland, especially under the action of storms, threatening the occupations closest to the beach dune limit. For the accomplishment of this work, were used a total of 258 field photographs taken monthly from a UAV (DJI ${ }^{\circ}$ Phantom 3 Professional) for orthophotomosaic construction. Additionally, oblique photographs (200) were collected, as well as data derived from two wavebuoys and a meteorological station, seeking to better understand the mobility rates of the shoreline, due to erosion and recomposition of the frontal dunes. The calculations of coastline variation were performed using the change polygon method. The results demonstrate the dynamics of the shoreline, with emphasis on a significant setback when an extreme wave event from S quadrant occurred in October 2016, where there was an average setback of $13.8 \mathrm{~m}$ between October and November of the same year. It was also identified periods of aeolian recomposition of the frontal dunes under the NE winds. However, during the monitoring performed, there were no significant recomposition rates compared to the setback rates. The results also point to the potentialities of using the UAV tool in coastal morphodynamic studies, which can be used for both qualitative analysis (oblique photographs) and quantitative analysis (vertical photographs).
\end{abstract}

Keywords: Beach dune limit; coastal erosion; UAV (drone); change polygon method; frontal dunes. 


\section{Introdução}

As praias existem em todas as áreas sedimentares costeiras expostas a ondas. Elas estão entre os sistemas físicos mais dinâmicos da superfície da terra, ocorrendo em costas onde haja sedimentos suficientes para que as ondas os depositem acima do nível do mar (Short 1999). Nesta temática, Bird (2008) destaca que existem praias relativamente estáveis ao longo de décadas, embora a grande maioria apresente mudanças rápidas, especialmente após a passagem de tempestades.

Como consequência do dinamismo inerente a esses sistemas, inúmeras orlas de praias urbanizadas sofrem com a erosão costeira, uma vez que os responsáveis por controlar os processos de ocupação, muitas vezes não tomam conhecimento do tipo de sistema praial que está sendo ocupado, ou sua disponibilidade sedimentar, seus ecossistemas e os impactos causados pela ocupação (Klein \& Short 2016). Este fato ocasiona uma série de problemas relacionados, sendo os mais relevantes, aqueles provenientes da interação entre a ocupação não planejada com áreas sujeitas a processos naturais de erosão costeira.

Calliari et al. (2003) apontam que o acompanhamento espaço-temporal de ciclos de erosão/deposição e a definição de estágios esperados de variação morfológica e de linha de costa pode aumentar consideravelmente o grau de sucesso de diversas atividades relacionadas ao gerenciamento costeiro específico a praias, principalmente as que sofrem erosão.

$\mathrm{Na}$ costa do RS, o segmento localizado a leste da Lagos dos Patos, municípios de São José do Norte, Tavares e Mostardas, apresenta pouca densidade populacional, com pequenas aglomerações urbanas junto a faixa de praia, sendo as cinco mais significativas: o balneário Praia do Mar Grosso, em São José do Norte, o balneário Praia do Farol em Tavares, e os balneários Mostardense, São Simão e Solidão, localizados no município de Mostardas. Estudos anteriores realizados no balneário Mostardense e nas adjacências como os de Simões (2015, 2018), Leal (2016), Simões \& Oliveira (2017), Simões et al. (2017) e Leal et al. (2018) retrataram um recuo significativo do limite superior da praia em direção a área urbanizada entre 2005 e 2017 a partir de diferentes metodologias. Simões (2015) também identificou o soterramento e remoção de ocupações em decorrência da remobilização eólica das dunas no local.

Para buscar um aprofundamento destas questões, o presente trabalho apresenta resultados de um monitoramento mensal da linha de costa e dunas frontais a partir de fotografias de VANT (Veículo aéreo não tripulado) ou ("drone" como é popularmente conhecido), ao longo de um ano. Dados adicionais, tais como derivados de dois ondógrafos e uma estação meteorológica, foram utilizados para conjuntamente com os dados de VANT, compreender melhor as taxas de mobilidade da linha de costa, fruto da erosão e recomposição do limite superior da praia (base da duna frontal). $\mathrm{O}$ entendimento disto pode ser relevante no planejamento e gerenciamento ambiental da área, e de outras localidades costeiras com características similares.

\section{2. Área de estudo}

A área de estudo situa-se no segmento do litoral do Rio Grande do Sul conhecido como litoral médio, mais especificamente no município de Mostardas (figura 1). O principal acesso até o Balneário Mostardense é através da BR 101, até o centro de Mostardas. Para acessar a área de estudo, partindo do centro de Mostardas, há uma via não pavimentada de aproximadamente $14 \mathrm{~km}$ que leva até o Balneário Mostardense.

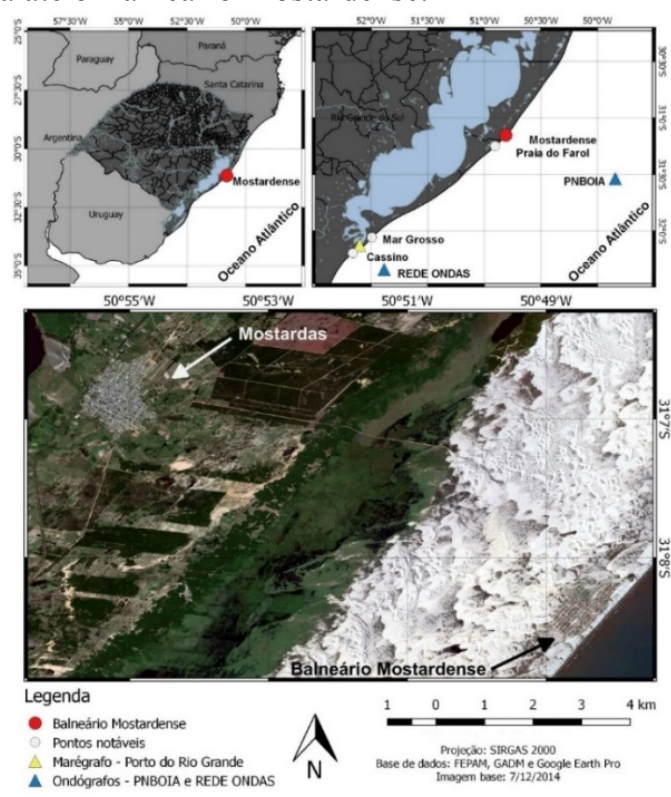

Figura 1: Mapa de localização da área de estudo

A costa do Rio Grande do Sul, ao longo de mais de 600 km, apresenta uma orientação geral NordesteSudoeste, com praias arenosas retilíneas e contínuas, predominantemente dominadas por ondas (Calliari et al. 2005, Calliari \& Toldo Jr. 2016). Todavia, superimposto nesta orientação geral, existem segmentos levemente côncavos e convexos (Dillenburg et al. 2005, 2009) ou, em outras palavras, leves sinuosidades (Calliari \& Toldo Jr. 2016) que se estendem desde os promontórios rochosos localizados em Torres até o Arroio Chuí na fronteira entre Brasil e Uruguai.

O litoral do Estado apresenta feições geomorfológicas decorrentes de transgressões e regressões marinhas, relacionadas a períodos interglaciais e glaciações respectivamente, caracterizado por sistemas do tipo laguna-barreira (Villwock \& Tomazelli 1995, Tomazelli \& Villwock 2000), sendo a porção emersa representada por quatro distintos sistemas deposicionais transgressivos-regressivos, denominados sistemas Laguna-barreira I, II, III e IV.

Em praticamente toda costa do RS existe uma barreira arenosa holocênica, regionalmente conhecida como barreira IV, com uma orientação predominante NE-SW (Tomazelli \& Villwock 2000). Esta possui certas sinuosidades, declividades suaves, algumas desembocaduras lagunares e pequenas drenagens, 
conhecidas regionalmente como sangradouros. Apesar de uma aparente homogeneidade, existem heterogeneidades em seus depósitos, uma vez que coexistem temporalmente barreiras de naturezas progradante, retrogradante e agradante (Dillenburg et al. 2005). Dillenburg et al. (2009) demonstram uma subdivisão da costa do RS em 4 setores, sendo os setores I e III os com tendência progradante e uma morfologia côncava e os setores II e IV com tendência retrogradante e uma morfologia convexa. Neste contexto, a área de estudo está localizada no segmento II (convexo), com uma barreira holocênica relativamente larga, apresentando um vasto campo de dunas móveis (figura $1)$.

A área de estudo, com base na classificação de Davis (1964), é dominada por ondas e encontra-se em uma zona de micro-maré, com regime semi-diurno e com amplitude máxima em torno de 0,32 $\mathrm{m}$ (Toldo Jr. et al. 2006). Marés meteorológicas positivas podem causar o empilhamento de ondas na praia excedendo a maré astronômica em até $1,2 \mathrm{~m}$ (Almeida et al. 1997). Pereira et al. (2010) salientam que as praias do Rio Grande do Sul são majoritariamente expostas a ação das ondas e compostas predominantemente por areia fina quartzosa, resultando em inclinações bastante suaves. Todavia, nas proximidades de Mostardas, as praias apresentam um pequeno aumento na porcentagem de areia de granulometria média, possuindo características morfodinâmicas classificadas como intermediárias, podendo variar entre banco e cava longitudinal a banco e praia rítmica, com moderada a alta mobilidade sedimentar (Barletta 2000, Pereira et al. 2010).

Segundo Barletta (2006), existe uma relação entre a morfologia da antepraia e os padrões de refração de ondas, os quais interferem sobre a distribuição de alturas e direções de ondas ao longo de grandes trechos do litoral médio do RS, fato relevante principalmente na adjacência sul da área de estudo, onde a isóbata de $20 \mathrm{~m}$ é mais próxima a costa, podendo expor a área de estudo a uma energia de ondas maior. Este fato é importante uma vez que a costa do RS é regularmente atingida por tempestades, que geram ondas provenientes do quadrante $\mathrm{S}$ e marés meteorológicas significativas, com potencial para ocasionar erosão no perfil praial.

Salienta-se ainda que o transporte longitudinal de sedimentos ocorre em duas direções: SW-NE e NE-SW. Todavia o transporte mais efetivo de sedimentos ocorre durante a passagem de frentes frias, transportando os sedimentos de SW para NE (Calliari \& Toldo Jr. 2016). Nicolodi et al. (2003), ao realizar um estudo sobre as correntes costeiras induzidas por tempestades no litoral médio do RS, constataram que essas correntes são excepcionalmente intensas quando associadas a passagem de frentes frias, acumulando água na costa e resultando em marés meteorológicas positivas que quando combinadas à ondas de alta energia, podem ocasionar processos de erosão costeira e elevado transporte de sedimentos. Estes autores também salientam o elucidado por Lima et al. (2001), que demonstraram que apesar de as ondas provenientes do quadrante $\mathrm{S}$ ocorrerem com menor frequência ( $9 \%$ ), elas são responsáveis por mais de $30 \%$ do total do transporte longitudinal, enquanto que as ondas de N-NE (cerca de $13 \%$ ) produzem apenas $2 \%$ do transporte, segundo os autores.

A orientação da linha de costa na área, somada a fatores morfodinâmicos, podem ser os responsáveis pela mobilidade praial (Absalonsen \& Toldo Jr. 2007), uma vez que praias intermediárias do litoral médio apresentam mobilidade sedimentar moderada a alta se comparada a outros segmentos da costa do RS, sendo que as flutuações anuais da linha de costa podem apresentar um padrão ondulatório, com áreas em erosão e acreção adjacentes (Esteves 2006).

Em relação à dinâmica eólica, Calliari et al. (2005) constataram que os ventos predominantes de NE são o fator mais relevante para a diferenciação na altura das dunas frontais, tanto no litoral norte como no litoral médio do RS. Estes autores ainda destacam que a orientação da linha de costa em relação ao vento predominante NE age sobre as dunas frontais, ao longo do litoral norte e médio do RS. Segundo Calliari et al. (2005), no RS, a orientação da linha de costa parece ser o fator mais relevante para a movimentação das dunas frontais frente ao vento predominante, podendo transportar a areia em direção à retroterra ou em direção ao oceano, ocasionando alterações na morfologia da praia e na dinâmica do transporte de sedimentos. Este transporte eólico em determinados setores se dá obliquamente à linha de costa, carregando sedimentos do pós-praia em direção ao cordão de dunas frontal, ou transportando sedimentos em sentido ao oceano adjacente. Neste contexto, pode-se afirmar que a formação dos campos de dunas na área é favorecida em função do alto aporte sedimentar, conjuntamente com a baixa umidade e o alto potencial de deriva eólica (Martinho 2008, Scottá et al. 2015). Scottá et al. (2015) através da análise de imagens orbitais, calcularam o deslocamento dos campos de dunas do Parque Nacional da Lagoa do Peixe, nas adjacências da área de estudo, entre os anos de 1986 a 2014, com setores variando entre $347 \mathrm{~m}$ a mais de $1500 \mathrm{~m}$ no período. Salienta-se ainda que o balneário Mostardense possui uma extensa faixa de dunas móveis na retaguarda (Pereira et al. 2010, Oliveira et a1. 2015).

\section{Materiais e métodos}

\subsection{Aquisição e processamento de fotografias aéreas}

O VANT utilizado para a aquisição das fotografias analisadas neste trabalho (DJI ${ }^{\circledR}$ Phantom 3 Professional) é de responsabilidade do Laboratório de Geomorfologia e Recursos Hídricos - Programa de PósGraduação em Geografia - FURG. Trata-se de um quadricóptero equipado com uma câmera de 12 megapixels. Este equipamento pesa pouco mais de $1 \mathrm{~kg}$ e pode operar com segurança a até cerca de $2 \mathrm{~km}$ de distância do rádio transmissor, com possibilidade de telemetria (transmissão de vídeo da câmera acoplada em tempo real e informações de demais sensores), a partir 
de utilização de um tablet ou smartphone conectado ao transmissor de rádio (figura 2).

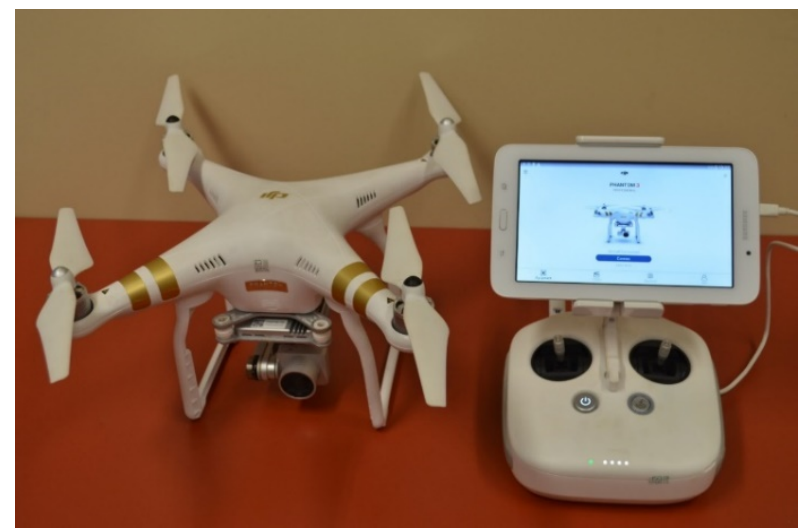

Figura 2: DJI Phantom 3 professional e controle remoto do equipamento, com tablet acoplado.

\subsection{Trabalhos de campo}

Foram realizadas 13 campanhas amostrais mensais entre junho de 2016 e junho de 2017, buscando compreender a movimentação da linha de costa no local, no período de um ano. $\mathrm{Na}$ área de estudo foram realizados voos paralelos à linha de costa, contemplando parte da zona de surf, todo o pós-praia, as dunas frontais e a primeira linha de urbanização diretamente defrontante ao oceano. Foram coletadas ao todo 258 fotografias verticais, onde o ângulo entre a linha do horizonte e a lente da câmera é de $90^{\circ}$, com uma tolerância de $3^{\circ}$ para mais ou para menos (Disperati 1995, Jensen 2009). Este tipo de fotografia possui o intento de quantificar os processos atuantes a partir do processamento das imagens obtidas. Os voos foram realizados com pilotagem manual no horário entre as 10 e as 15 horas, buscando um ângulo solar favorável, e uma altura constante segundo dados da telemetria do equipamento. A tabela 1 demonstra as datas dos trabalhos de campo, o RMS do registro de cada mosaico e outros dados relevantes.

Tabela 1: Trabalhos de campo realizados com o VANT DJI® Phantom 3 Professional.

\begin{tabular}{|c|c|c|c|c|c|c|}
\hline $\begin{array}{l}\text { Data de } \\
\text { aquisição }\end{array}$ & $\begin{array}{l}\text { Horário } \\
\text { do voo }\end{array}$ & $\begin{array}{l}\text { Total de } \\
\text { fotografias } \\
\text { verticais }\end{array}$ & $\begin{array}{l}\text { Total de } \\
\text { fotografias } \\
\text { obliquas }\end{array}$ & $\begin{array}{l}\text { Intensidade, } \\
\text { Rajadas }(m / s) e \\
\text { direçao }\left({ }^{\circ}\right) \text { do } \\
\text { vento }\end{array}$ & $\begin{array}{l}\text { Tamanho do } \\
\text { pixel }(\mathrm{cm})\end{array}$ & $\begin{array}{l}\text { RMS- } \\
\text { Erro médio } \\
\text { quadrático } \\
\text { (m) }\end{array}$ \\
\hline 15/6/2016 & $\begin{array}{l}11: 40 \mathrm{a} \\
11: 49\end{array}$ & 9 & 12 & $\begin{array}{l}\text { Int. 1,1 Raj. 2,2 } \\
\text { Dir. } 129^{\circ}\end{array}$ & $16,9 \mathrm{~cm}$ & 0,003 \\
\hline $8 / 7 / 2016$ & $\begin{array}{l}10: 58 \mathrm{a} \\
11: 10\end{array}$ & 9 & 13 & $\begin{array}{l}\text { Int. 1,6 Raj. 4,6 } \\
\text { Dir. 291 }\end{array}$ & $16,5 \mathrm{~cm}$ & 0,114 \\
\hline 13/8/2016 & $\begin{array}{l}10: 16 \text { as } \\
13: 28\end{array}$ & 25 & 11 & $\begin{array}{l}\text { Int. } 4,6 \text { Raj. } 8,5 \\
\text { Dir. } 322^{\circ}\end{array}$ & $16,6 \mathrm{~cm}$ & 0,006 \\
\hline 9/9/2016 & $\begin{array}{l}\text { 11:02 as } \\
11: 38\end{array}$ & 14 & 14 & $\begin{array}{l}\text { Int. 3,4 Raj. 5,0 } \\
\text { Dir. 66 }\end{array}$ & $16,4 \mathrm{~cm}$ & 0,048 \\
\hline $10 / 10 / 2016$ & $\begin{array}{l}10: 21 \text { as } \\
10: 34\end{array}$ & 18 & 4 & $\begin{array}{l}\text { Int. 3,7 Raj. 5,5 } \\
\text { Dir. } 85^{\circ}\end{array}$ & $16,8 \mathrm{~cm}$ & 0,004 \\
\hline $5 / 11 / 2016$ & $\begin{array}{l}10: 09 \text { as } \\
10: 17\end{array}$ & 20 & 27 & $\begin{array}{l}\text { Int. 4,2 Raj. 6,5 } \\
\text { Dir. } 56^{\circ}\end{array}$ & $17,2 \mathrm{~cm}$ & 0,049 \\
\hline $7 / 12 / 2016$ & $\begin{array}{l}10: 10 \text { as } \\
12: 03\end{array}$ & 13 & 11 & $\begin{array}{l}\text { Int. } 4,3 \text { Raj. } 5,7 \\
\text { Dir. } 174^{\circ}\end{array}$ & $17,1 \mathrm{~cm}$ & 0,080 \\
\hline $12 / 1 / 2017$ & $\begin{array}{l}11: 29 \text { as } \\
11: 41\end{array}$ & 12 & 4 & $\begin{array}{l}\text { Int. 4,1 Raj. } 5,5 \\
\text { Dir. } 65^{\circ}\end{array}$ & $17,2 \mathrm{~cm}$ & 0,050 \\
\hline $7 / 2 / 2017$ & $\begin{array}{l}11: 32 \text { as } \\
11: 41\end{array}$ & 19 & - & $\begin{array}{l}\text { Int. } 7,9 \text { Raj. } 10,3 \\
\text { Dir. } 191^{\circ}\end{array}$ & $17 \mathrm{~cm}$ & 0,027 \\
\hline $7 / 3 / 2017$ & $\begin{array}{l}\text { 12:26 às } \\
\text { 12:36 }\end{array}$ & 23 & 2 & $\begin{array}{l}\text { Int. } 5,0 \text { Raj. } 6,3 \\
\text { Dir. } 139^{\circ}\end{array}$ & $17,5 \mathrm{~cm}$ & 0,082 \\
\hline $5 / 4 / 2017$ & $\begin{array}{l}11: 13 \text { às } \\
14: 31\end{array}$ & 41 & 28 & $\begin{array}{l}\text { Int. } 4,3 \text { Raj } 7,6 \\
\text { Dir. } 294^{\circ}\end{array}$ & $17,3 \mathrm{~cm}$ & 0,074 \\
\hline 5/5/2017 & $\begin{array}{l}\text { 11:24 às } \\
11: 36\end{array}$ & 29 & 11 & $\begin{array}{l}\text { Int. } 2,0 \text { Raj. } 4,6 \\
\text { Dir. } 191^{\circ}\end{array}$ & $17,1 \mathrm{~cm}$ & 0,051 \\
\hline $14 / 6 / 2017$ & $\begin{array}{l}\text { 14:09 as } \\
15: 08\end{array}$ & 26 & 65 & $\begin{array}{l}\text { Int.3,8 Raj. } 5,0 \\
\text { Dir. 52 }\end{array}$ & $16,3 \mathrm{~cm}$ & $\begin{array}{l}\text { Mosaico } \\
\text { BASE }\end{array}$ \\
\hline
\end{tabular}

Fotografias aéreas oblíquas e em solo também foram adquiridas, possibilitando uma melhor interpretação dos dados obtidos pelas fotografias verticais.

Para tornar possível a realização deste estudo foi adotada uma "janela metodológica" ou "janela meteorológica", já que se trata de um intervalo de 11 dias (do dia 5 ao dia 15 de cada mês), onde o objetivo foi de buscar as melhores condições meteorológicas possíveis dentro deste período para a realização dos voos. É importante salientar que em operações realizadas com VANT, é imprescindível se considerar a previsão do tempo, pois diversos fatores meteorológicos podem inviabilizar a coleta de dados como: presença de nuvens a baixa altitude, precipitação e ventos acima dos $40 \mathrm{~km} / \mathrm{h}$. Estas precauções foram importantes no intuito de garantir a integridade do equipamento bem como de todos em seu entorno, evitando quedas.

\subsection{Processamento das fotografias verticais}

Todas as fotografias obtidas em cada uma das 13 campanhas amostrais foram agrupadas em mosaicos de fotografias verticais, criados com o auxílio do software Agisoft Photoscan ${ }^{\circledR}$, que se utiliza dos metadados das fotografias fornecidas pelo VANT, para construir ortofotomosaicos. Este software baseia-se em algoritmos SfM (Structure from Motion) e correlação densa de imagens, possuindo ferramentas que facilitam o processo de criação dos ortofotomosaicos e demais produtos associados. Isto permite ao operador controlar cada etapa do processo, desde o alinhamento das fotografias, a construção de nuvem de pontos de correlação, a inserção de pontos de controle, a elaboração de texturas, a construção de um modelo digital de superfície e do ortofotomosaico. Maiores detalhes sobre os procedimentos de aquisição e processamento de fotografias de VANT realizados neste trabalho, podem ser obtidos em Simões et al. (2019).

Para tornar possível a realização de comparações entre os mosaicos produzidos, e melhorar a acurácia dos dados, estes passaram por dois processos: Georreferenciamento e registro. Estes processos foram realizados no software ArcMap 10.3 da plataforma ArcGIS $®$. Para tal foram utilizados dados coletados por receptor geodésico em campo. Estes pontos de controle foram coletados nos trabalhos de campo realizados em julho de 2016 e junho de 2017. Os pontos de controle (X, Y, Z) coletados em julho de 2016 e junho de 2017 foram utilizados para o georreferenciamento dos mosaicos de fotografias aéreas verticais. $\mathrm{O}$ equipamento utilizado para coleta dos pontos de controle nos trabalhos de campo realizados foi um receptor geodésico da marca Leica Viva ${ }^{\circledR}$ GS15 GNSS. Todos os pontos coletados foram registrados pelo modo stop-and-go. A antena da estação base permaneceu fixa no ponto de apoio altimétrico.

O mosaico escolhido para ser georreferenciado foi o elaborado a partir dos dados obtidos em junho de 2017, com auxílio de mais de 40 pontos coletados com receptor geodésico em campo. Este mosaico serviu de base para o registro de todos os outros mosaicos. $\mathrm{O}$ 
processo de registro dos mosaicos utilizou de 60 a 120 pontos de controle para cada mosaico. Este processo permitiu que se realizasse o cálculo do erro médio quadrático do registro (RMS - Root Mean Square Error) que apresentou valores abaixo de um pixel (tabela 1).

A variação mensal ao longo de um ano do limite praiaduna foi calculada a partir da vetorização da base da duna frontal em todos os 13 mosaicos construídos de junho de 2016 a junho de 2017. A variação foi calculada para os intervalos de aquisição de dados, ou seja: de 15/6/2016 a 8/7/2016, 8/7/2016 a 13/8/2016 e assim consecutivamente. Todos os cálculos utilizaram-se do método do polígono de mudança (Smith \& Cromley 2012), também utilizado com sucesso na costa do RS por Albuquerque (2013), Albuquerque et al. (2013), Leal (2016), Leal et al. (2018), Simões (2018), Albuquerque et al. (2018), Oliveira et al. (2019) e Simões et al. (2019).

\subsection{Condições meteo-oceanográficas entre maio de 2016 e junho de 2017}

Para compreender os processos atuantes na área de estudo, dados oceanográficos e meteorológicos também foram investigados ao longo do período do monitoramento, com intuito de comparar essas informações com os dados obtidos pelo monitoramento com VANT, visando discutir sua influência nos resultados. Para isto, foram analisadas séries de dados de onda de dois ondógrafos e dados de vento, precipitação, umidade, temperatura e radiação solar obtidos junto a uma estação meteorológica automática. Estas condições influenciaram tanto na retração como na recomposição do limite praia-duna, e foram adquiridas entre o período anterior a cada uma das saídas a campo (maio 2016 a junho 2017).

Os dados de onda foram extraídos dos dois ondógrafos situados mais próximos a área de estudo (PNBOIA Localizado a cerca de $100 \mathrm{~km}$ da costa de Mostardas, e Rede Ondas - Localizado próximo da desembocadura da Lagoa dos Patos em Rio Grande). Ambos os dados possuíam alguns "buracos" na série, onde foi inserido um valor "no data" nestes casos. Os dados de onda forneceram informações sobre altura e direção das ondas incidentes. Ressalta-se que apenas a condição mais energética de onda foi disponibilizada no site, podendo existir condições de onda secundárias, as quais não foram analisadas. Alguns dias após a passagem de um evento hidrodinâmico extremo em outubro de 2016, o ondógrafo próximo a desembocadura da Lagoa dos Patos (Rede Ondas), parou de fornecer dados, permanecendo inativo até o final do recorte temporal da pesquisa. Também foram utilizados dados de um ondógrafo do programa PNBOIA (Programa Nacional de Boias), situado a cerca de $100 \mathrm{~km}$ da costa do litoral médio, na área oceânica defrontante ao balneário Mostardense. Deste, foram extraídos dados de altura, período e direção das ondas ao longo de praticamente todo o período de monitoramento. Os dados deste ondógrafo são fornecidos pela Marinha do Brasil e estão disponíveis no site: http://www.mar.mil.br/dhn/chm/me teo/prev/dados/pnboia/boia_rg.htm
Os dados meteorológicos foram coletados no site do INMET (Instituto Nacional de Meteorologia), mais especificamente da Estação Meteorológica de Observação de Superfície Automática 86994, instalada na Praia do Farol de Mostardas, cerca de 13,5 km ao sul do balneário Mostardense. Esta estação disponibilizou dados de velocidade e direção do vento, precipitação, umidade, temperatura e radiação solar durante o período de maio de 2016 a junho de 2017. Os dados de vento foram processados no software WRplot View. Este dado foi processado mês a mês, ou seja, no período que antecedeu cada um dos trabalhos de campo realizados. Este processo gerou rosas de vento que demonstraram a intensidade dos ventos e sua direção, fato bastante importante para discutir os processos eólicos atuantes na área de estudo. Adicionalmente também foi elaborada uma rosa de vento demonstrando o comportamento durante todo o período. Os demais dados meteorológicos (radiação, chuva, temperatura e umidade instantânea) foram também analisados para todo o período de monitoramento.

\section{Resultados e discussão}

Este item foi subdividido em três partes. A primeira apresenta os resultados do monitoramento da linha de costa para análise quantitativa, a segunda demonstra dados meteo-oceanográficos do período, enquanto a última utiliza-se de fotografias obtidas em campo para consolidar a discussão.

\subsection{Variação do limite praia-duna entre 2016 e 2017}

A partir do acompanhamento mensal realizado, foram construídos ortofotomosaicos de fotografias aéreas verticais obtidas por VANT, sobre os quais foi realizada a vetorização do limite superior da praia (base da duna frontal), neste trabalho definido como o limite praiaduna. As figuras 3, 4 e 5, ilustram os 13 mosaicos obtidos, compostos de fotografias aéreas coletadas, processadas e analisadas pela presente pesquisa. A figura 3 demonstra a área de estudo no inverno de 2016. As dunas frontais do balneário são fragmentadas por sangradouros e arruamentos, fato observado em todos os ortofotomosaicos. O primeiro mosaico gerado em junho de 2016 apresenta uma área de estudo com características erosivas, com dunas frontais bastante escarpadas. Esta situação se manteve no mês posterior. Em julho de 2016 a praia apresentou um caráter ainda mais erosivo que em junho do mesmo ano. Em agosto de 2016, o mosaico gerado demonstra o início de uma recomposição da base das dunas frontais por ação eólica, mais nítido ao norte da praia. Em setembro de 2016, a figura 3 demonstra o aumento de características rítmicas na praia, com formação de cúspides praiais.

O mosaico de 10 de outubro de 2016 (figura 4) ilustra um período erosivo, mas com alguma presença eólica na base das dunas frontais. Já no mosaico de 11 de novembro de 2016, é possível observar a presença significativa de minerais pesados na base das dunas frontais e uma pequena berma. Este período é 
substancialmente importante, uma vez que nos dias 27 a 29 de outubro de 2016 ocorreu a passagem de um forte ciclone extratropical, que atingiu a costa do RS (Albuquerque et al. 2018, Oliveira et al. 2019) ocasionando retração de linha de costa generalizada. Em dezembro de 2016 é possível observar um lento início de recuperação da praia, apresentando características mais rítmicas e depósitos eólicos cobrindo a base das dunas frontais. No mosaico de janeiro de 2017, é possível observar claramente o contraste entre os minerais pesados próximos à base das dunas frontais, expostos no mosaico de 11 de novembro de 2016, e uma berma de acreção, caracterizando uma recomposição de parte do perfil praial.
A figura 5 mostra a praia em 2017, identificando claramente uma maior ação eólica sobre a praia que em 2016, sobretudo no mosaico de abril. Os mosaicos obtidos em fevereiro de 2017 e março de 2017 demonstram o processo de deslocamento sedimentar por ação eólica, onde parte do estoque sedimentar da berma migrou em direção a base das dunas frontais, continuando um processo de recomposição praial. Em abril de 2017 e maio de 2017 é possível identificar significativa ação eólica, tendo também cúspides praias bem definidas evidenciando suas características rítmicas. Em junho de 2017 com a proximidade do inverno, a praia demonstra novamente um perfil mais erosivo, com menos aporte eólico no pós-praia.

15/6/2016 - Monitoramento por drone
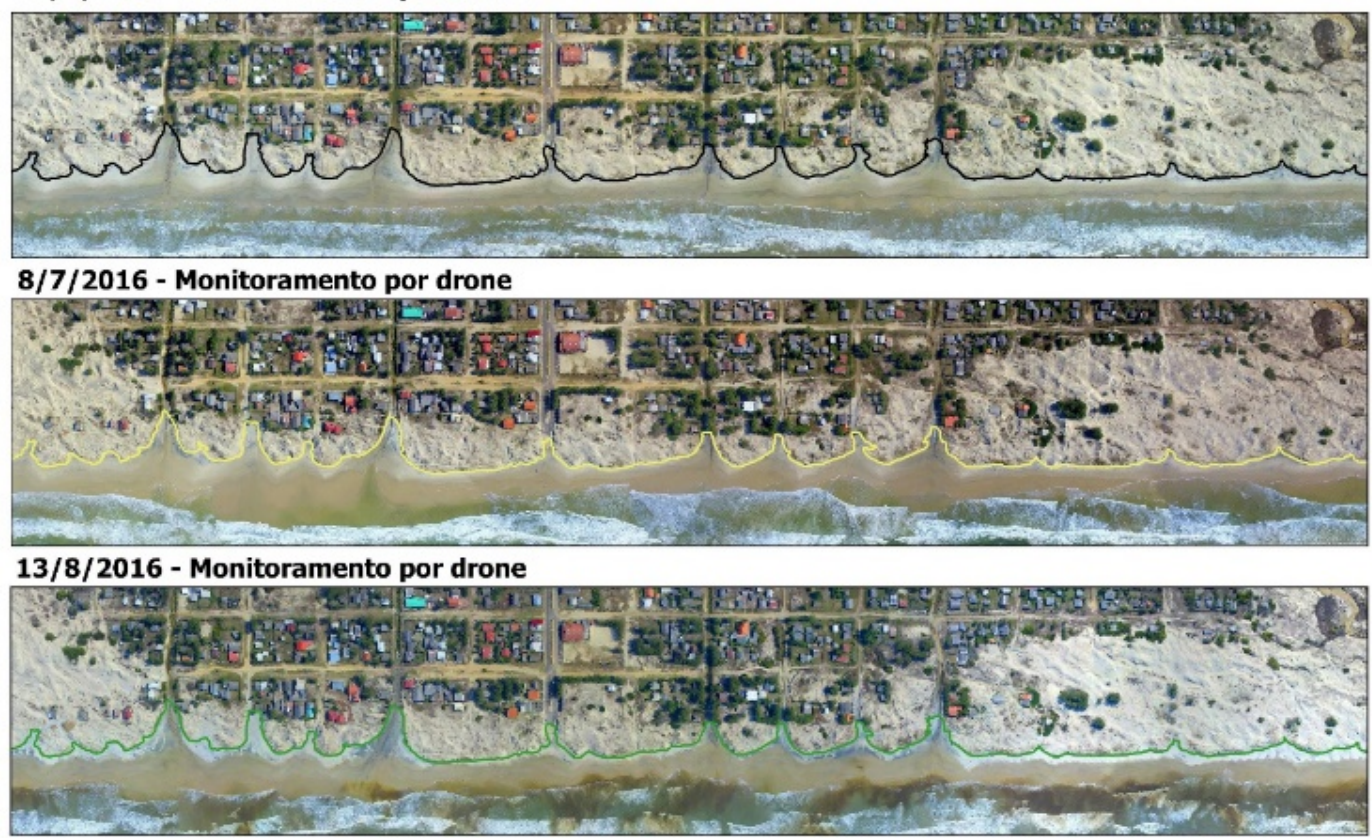

9/9/2016 - Monitoramento por drone

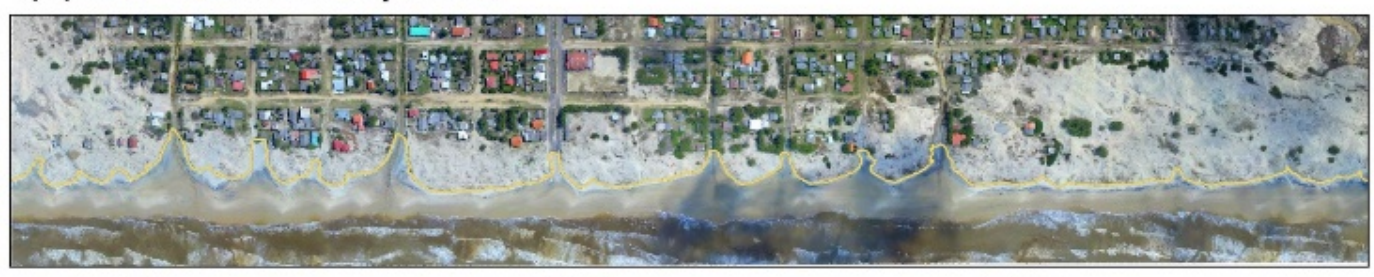

6553000

6553500

6554000

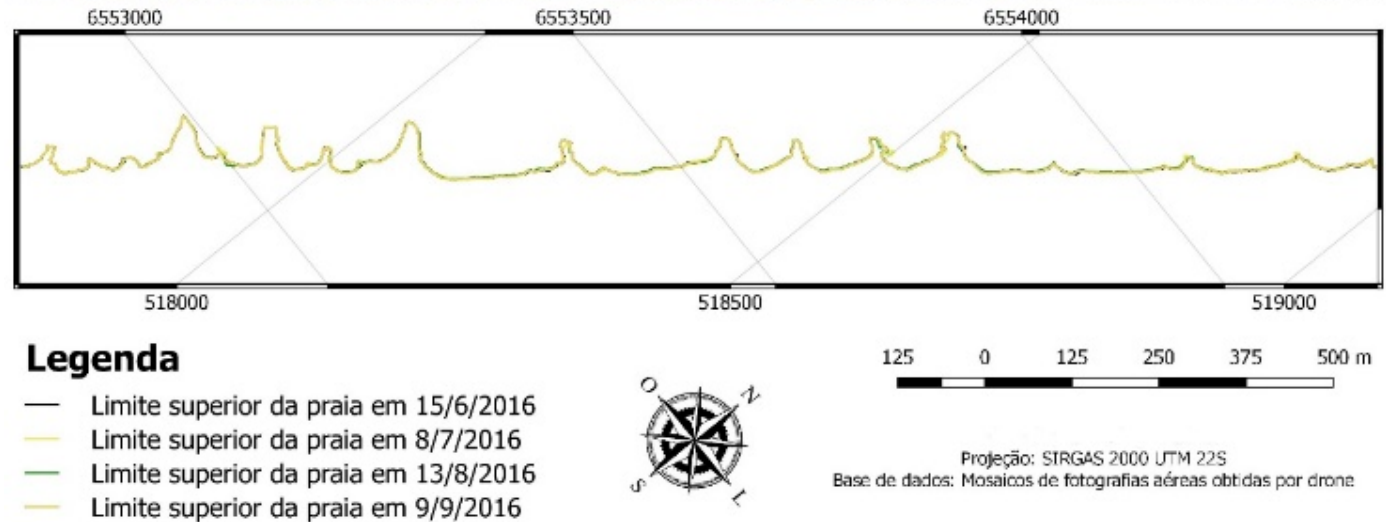

Figura 3: Mosaicos de fotografias aéreas obtidas por VANT utilizados na pesquisa e vetorizações das respectivas linhas de costa entre junho de 2016 e setembro de 2016. 
10/10/2016 - Monitoramento por drone

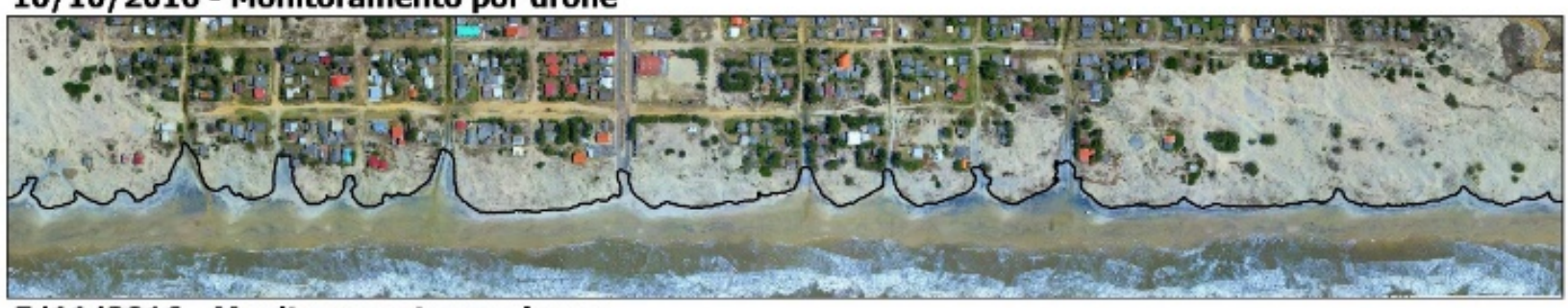

\section{5/11/2016 - Monitoramento por drone}

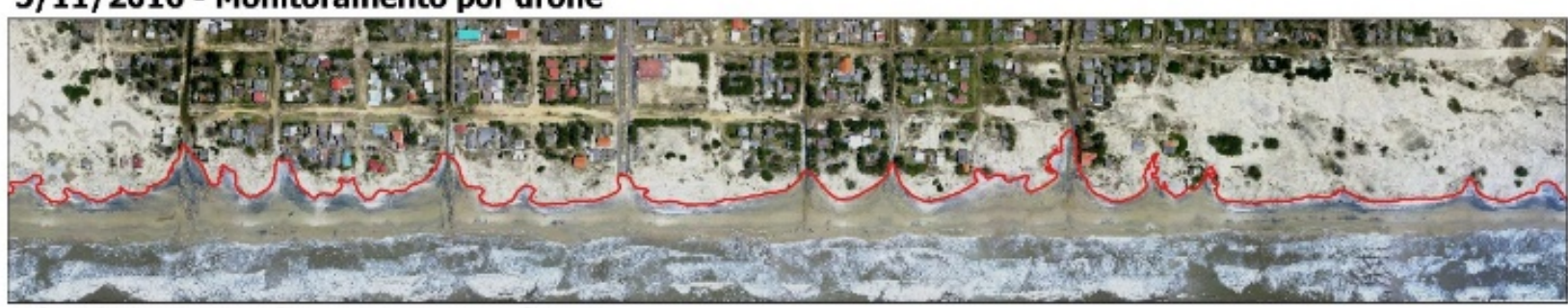

7/12/2016 - Monitoramento por drone

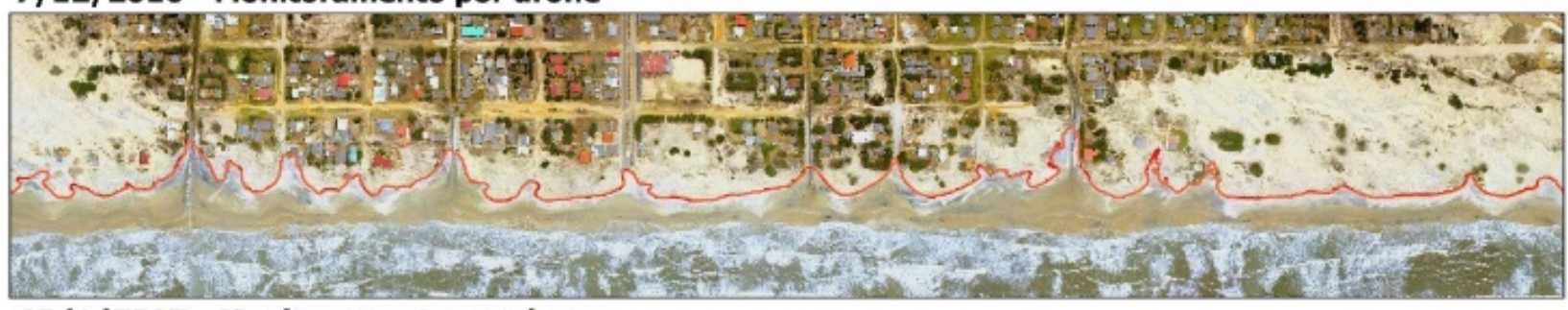

\section{2/1/2017 - Monitoramento por drone}

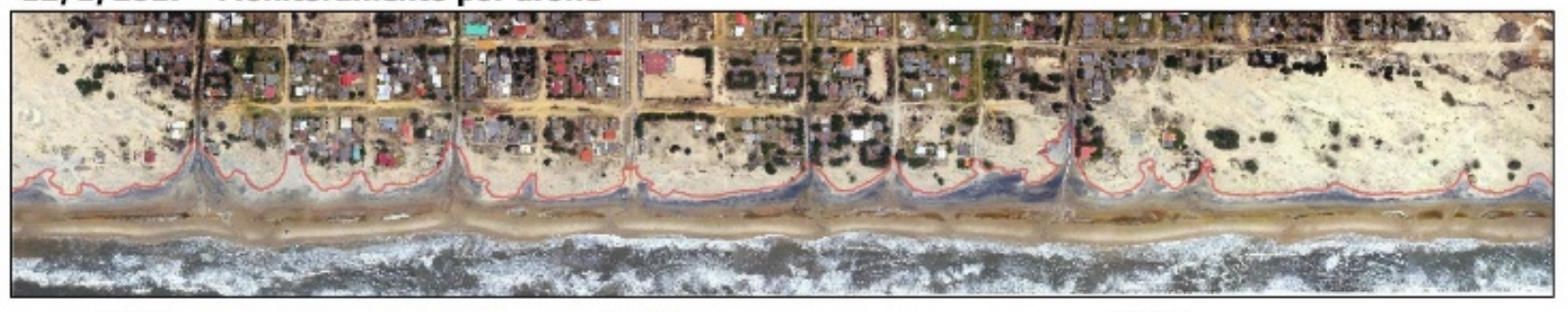

6553000

6553500

6554000

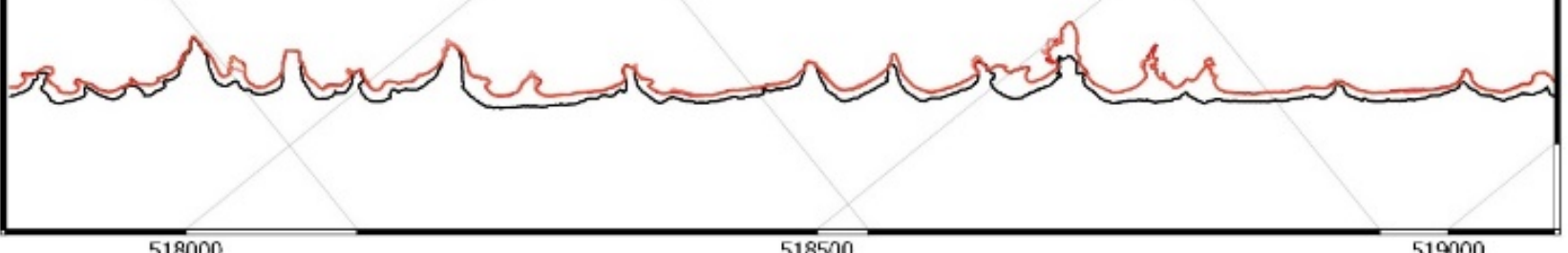

\section{Legenda}

- Limite superior da praia em 10/10/2016

- Limite superior da praia em 5/11/2016 Limite superior da praia em 7/12/2016

- Limite superior da praia em 12/1/2017

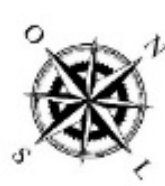

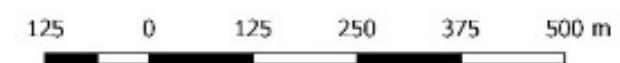

Projeça: SIRGAS 2000 UTM 225

Base de dadcos: Mosaicos de fotografias aéreas cobtidas por drone

Figura 4: Mosaicos de fotografias aéreas obtidos por VANT utilizados na pesquisa e vetorizações das respectivas linhas de costa entre outubro de 2016 e janeiro de 2017. 
7/2/2017 - Monitoramento por drone

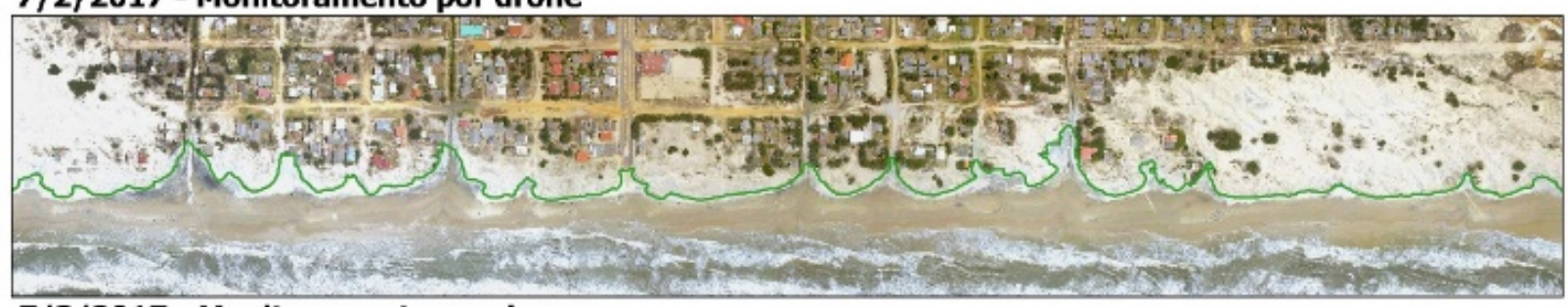

\section{7/3/2017 - Monitoramento por drone}

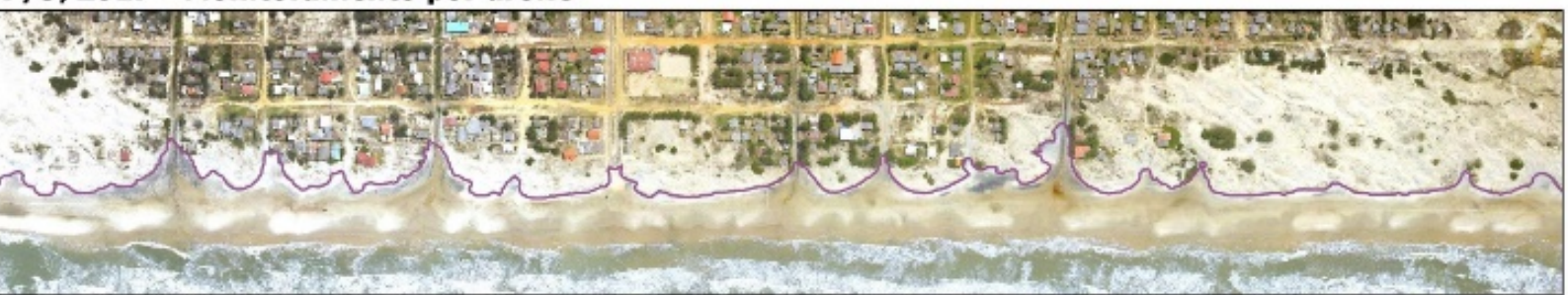

\section{5/4/2017 - Monitoramento por drone}

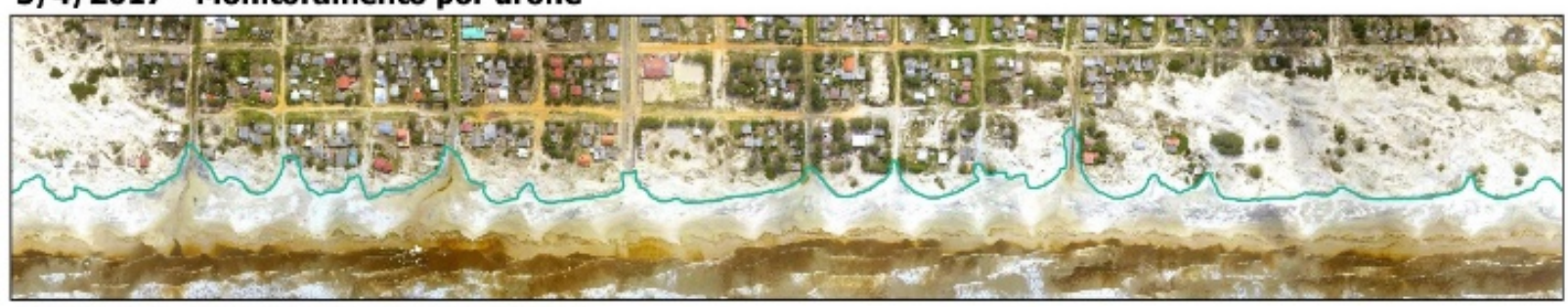

\section{5/5/2017 - Monitoramento por drone}

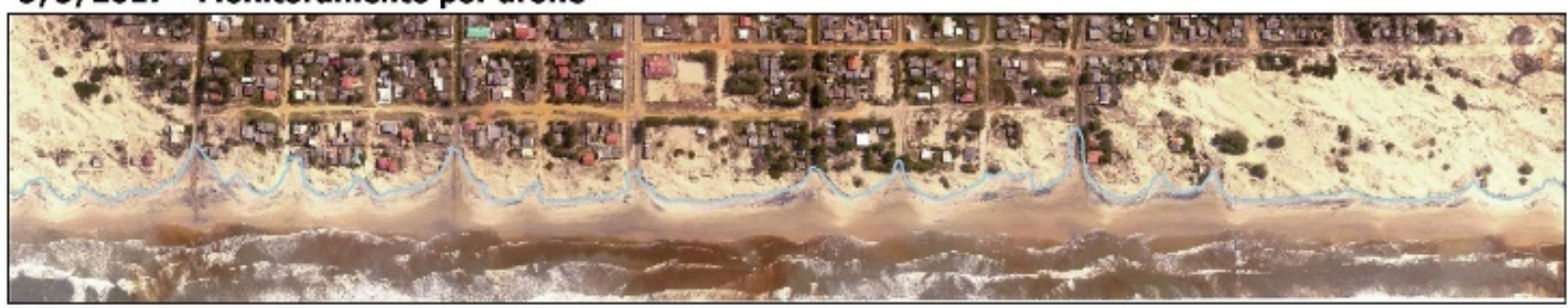

\section{4/6/2017 - Monitoramento por drone}
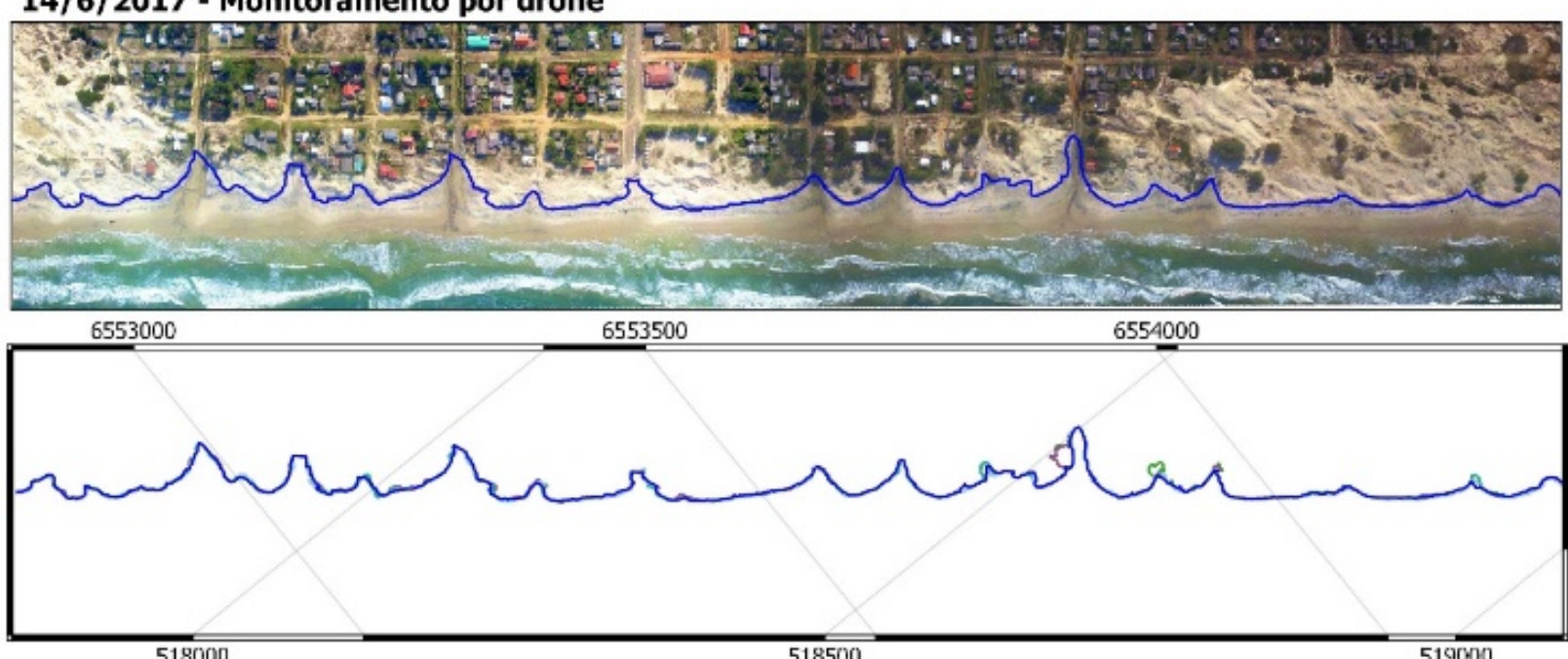

\section{Legenda}

- Limite superior da praia em 7/2/2017

- Limite superior da praia em 7/3/2017

- Limite superior da praia em 5/4/2017

- Limite superior da praia em 5/5/2017

- Limite superior da praia em 14/6/2017

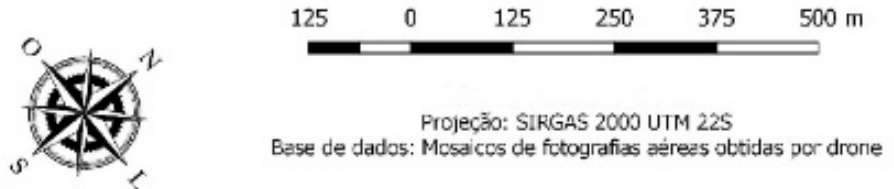

Figura 5: Mosaicos de fotografias aéreas obtidos por VANT utilizados na pesquisa e vetorizações das respectivas linhas de costa entre fevereiro de 2016 e junho de 2017. 
Com base nos ortofotomosaicos obtidos pelo VANT (figuras 3, 4 e 5), a variação da linha de costa (limite praia-duna) foi analisada mensalmente de forma

Variação da linha de costa entre 15/6/2016 a 8/7/2016 - Perda de 651,31 $\mathrm{m}^{2}$ de área de dunas - Erosão média de 0,32 m quantitativa a partir do método polígono de mudança (figuras 6 e 7).

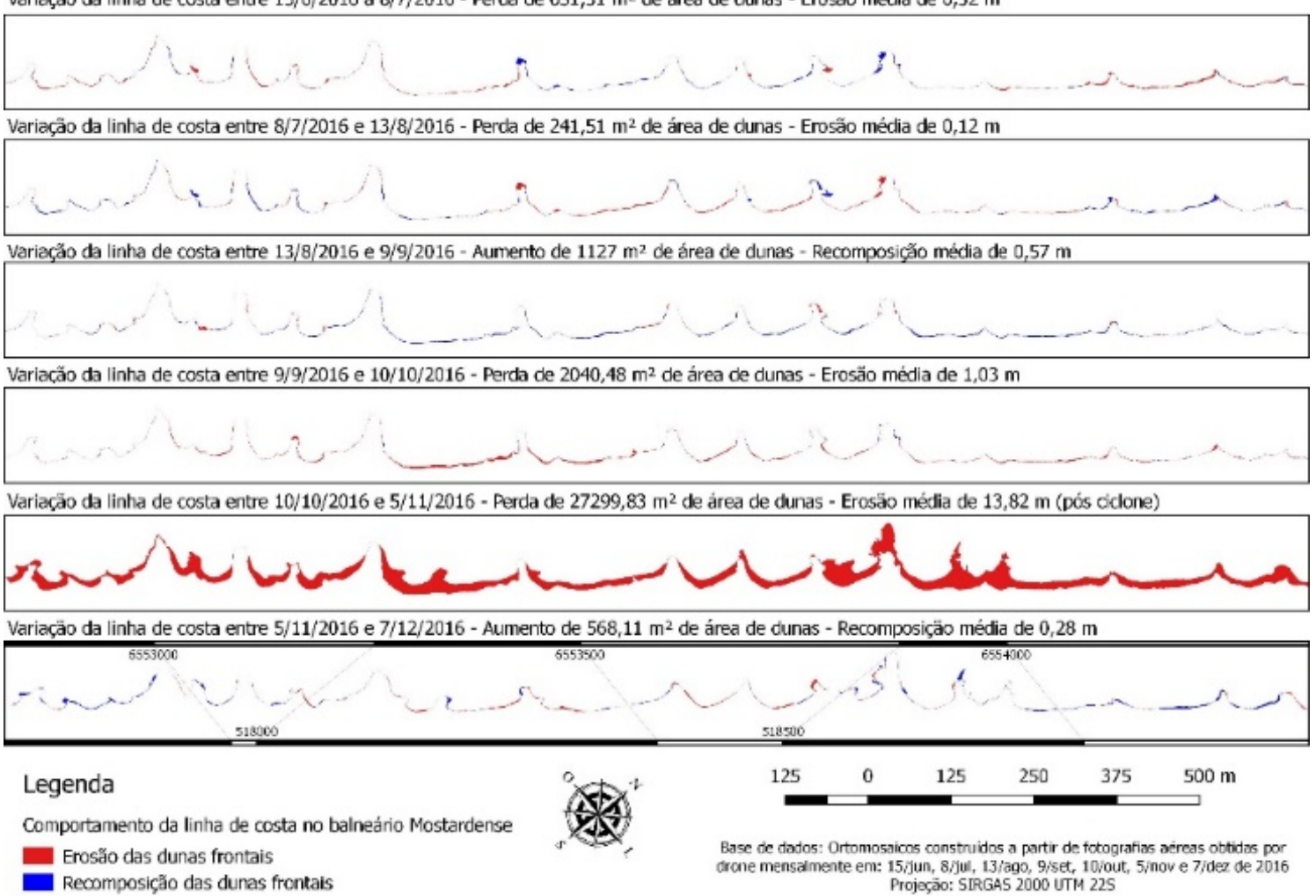

Figura 6: Variação da linha de costa no balneário Mostardense entre 15 de junho de 2016 e 7 de dezembro de 2016, utilizando fotografias aéreas de VANT.

Variaçăo da linha de costa entre 7/12/2016 a 12/1/2017 - Perda de 490,46 $\mathrm{m}^{2}$ de área de dunas - Erosão média de 0,25 m

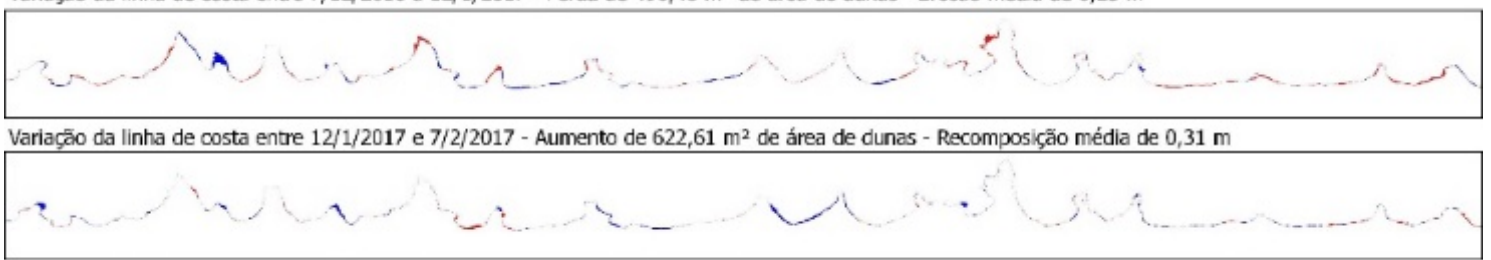

Variação da linha de costa entre 7/2/2017 e 7/3/2017 - Estabilidade da linha de costa - Pequenas variaçäes positivas e negativas - Balanço sedimentar nulo

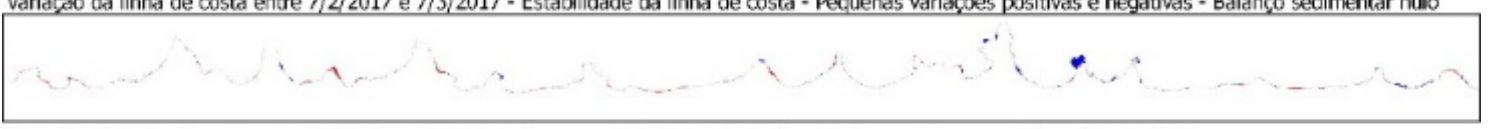

Variaçåo da linha de costa entre 7/3/2017 e 5/4/2017 - Aumento de $916,42 \mathrm{~m}^{2}$ de área de dunas - Recomposição média de 0,46 m

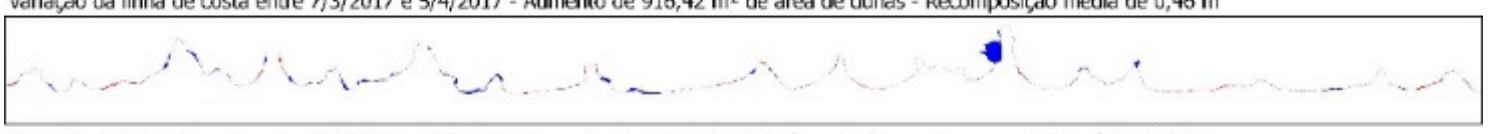

Variação da linha de costa entre 5/4/2017 e 5/5/2017 - Aumento de $1613,56 \mathrm{~m}^{2}$ de área de dunas - Recomposição média de 0,81 m

, the

Variação da linha de costa entre 5/5/2017 e 14/6/2017 - Perda de 1695,65 $\mathrm{m}^{2}$ de área de dunas - Erosão média de 0,85 m

(5is5000

Legenda

Comportamento da linha de costa no balneário Mostardense

Erosão das dunas frontais

Recomposiçăo das dunas frontais

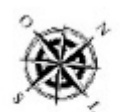

125

$\begin{array}{lllll}0 & 125 & 250 & 375 & 500 \mathrm{~m}\end{array}$

Base de dados: Ortomosaicos construidos a partir de fotografias aéreas abtidas por drone mersalmente am: 12/jan, 7/fer, 7/mar, 5atr, 5/mai e 14/jun de 2017

Figura 7: Variação da linha de costa no balneário Mostardense entre 7 de dezembro de 2016 e 14 de junho de 2017 utilizando fotografias aéreas de VANT. 
A partir do cálculo de variação de linha de costa, foram criados mapas com intuito de ilustrar os processos da dinâmica da linha de costa, retratando assim de forma didática a mobilidade do limite praia-duna ao longo do período de junho de 2016 até junho de 2017.

A figura 6 mostra que durante o segundo semestre de 2016, a praia apresentou um comportamento majoritariamente erosivo (-0,33 m entre 15 junho e 8 de julho; - $0,12 \mathrm{~m}$ entre 8 de julho e 13 de agosto; $-1,03 \mathrm{~m}$ entre 9 de setembro e 10 de outubro). A linha de costa do balneário Mostardense foi fortemente erodida entre 10 de outubro e 5 de novembro de 2016, tendo uma retração média de -13,8 m com uma redução da área de

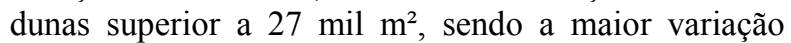
encontrada neste acompanhamento mensal. Durante o segundo semestre de 2016 ocorreram pequenas recomposições entre 13 de agosto e 9 de setembro de $2016(+0,57 \mathrm{~m})$ e entre novembro e dezembro de 2016 $(+0,29 \mathrm{~m})$.

Já a figura 7 demonstra o comportamento da linha de costa no balneário Mostardense, durante o primeiro semestre de 2017. Neste período, a linha de costa

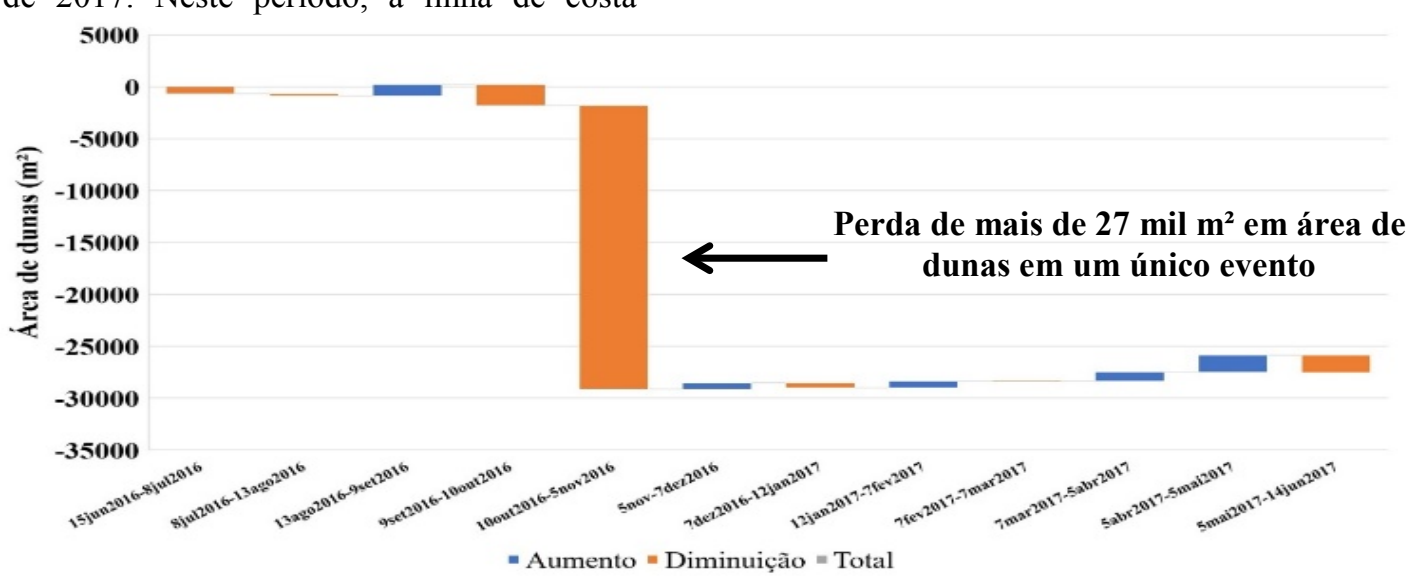

Figura 8: Variação mensal da área das dunas frontais do balneário Mostardense entre 15 de junho de 2016 e 14 de junho de 2017.

A figura 8 demonstra que a variação da linha de costa não foi um processo linear. Durante o intervalo analisado em uma frequência mensal, a linha de costa apresentou um comportamento relativamente estável, até a passagem do ciclone no final de outubro de 2016, apresentou mais períodos de recomposição sedimentar, entre 12 de janeiro e 7 de fevereiro $(+0,31 \mathrm{~m}), 7 \mathrm{de}$ março e 5 de abril $(+0,46 \mathrm{~m})$ e entre 5 de abril e 5 de maio $(+0,82 \mathrm{~m})$. Taxas erosivas ocorreram apenas entre os meses de dezembro de 2016 e janeiro de 2017 (-0,25 m), e maio de 2017 e junho de 2017 (-0,86 m), permanecendo o limite praia-duna praticamente estável de 7 de fevereiro a 7 de março.

Considerando todo o monitoramento, quando excluímos da análise os dados relativos ao ciclone ($13,8 \mathrm{~m}$ de recuo) e somamos os outros valores de retração $(-2,59 \mathrm{~m})$ e os valores de progradação $(+2,45$ $\mathrm{m})$, podemos observar que o limite praia-duna se manteve relativamente estável, com uma variação de apenas - $0,14 \mathrm{~m}$ no período. Ao compilar os dados das figuras 6 e 7, ainda foi possível construir um gráfico para ilustrar a não linearidade da variação da linha de costa. Este gráfico contempla os valores de variação de área dos polígonos (área de dunas) utilizados para o cálculo de variação média da linha de costa durante o período analisado (figura 8). e novamente apresentou um comportamento relativamente estável até o final do acompanhamento. Já a figura 9 demonstra o resultado da variação da linha de costa entre junho de 2016 e junho de 2017 ilustrando a área de dunas perdida no período.

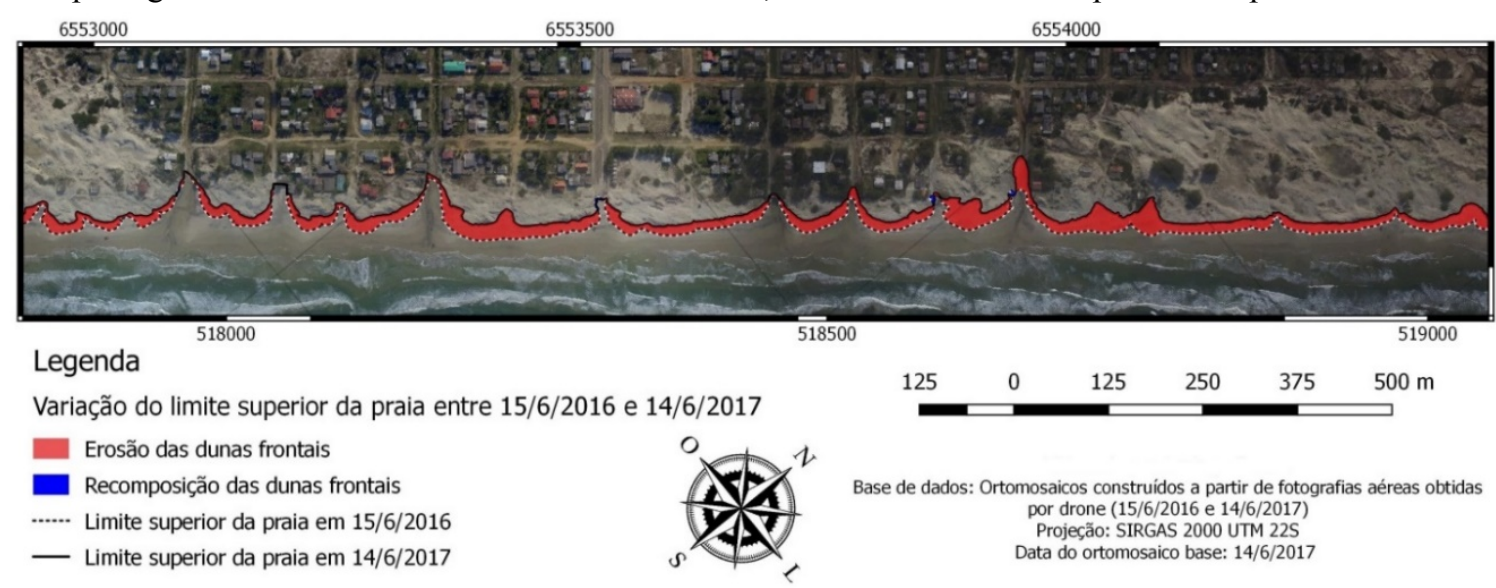

Figura 9: Variação da linha de costa no balneário Mostardense entre junho de 2016 e junho de 2017

Esta variação significativa demonstrada nas figuras 8 e 9, corresponde basicamente a passagem do ciclone

extratropical que ocorreu nos dias 27 a 29 de outubro estudado por (Albuquerque et al. 2018, Oliveira et al. 
2019), e descrito também neste trabalho. Estas medições realizadas mensalmente possibilitaram avaliar que apenas um evento de alta energia teve tamanha magnitude para gerar significativas alterações na linha de costa (limite praia-duna), podendo-se atribuir o recuo das dunas frontais no período entre as coletas quase que em sua totalidade ao ciclone de 27 a 29 de outubro. No entanto, mesmo atribuindo-se a retração das dunas caracterizadas no presente estudo, em grande parte ao evento do final de outubro de 2016, ressalta-se que uma sequência de tempestades de menor energia ocorreu anteriormente, durante o outono-inverno-primavera de 2016. Isto pode ter promovido, conforme Dolan \& Davis (1992), a geração de uma morfologia erosiva de praia, com erosão da face praial, redução da largura da berma da praia e aumento do gradiente do fundo, favorecendo o espraiamento da onda até a base da duna frontal durante este evento, considerado como extremo de alta energia de onda (Oliveira et al. 2019).

Ocorreram diversas alterações morfológicas no sistema praia duna durante a realização do monitoramento, na morfologia dos bancos, face da praia e cúspides praiais, deposições eólicas sobre a praia subaquosa e também variação eólica nas dunas e fluviomarinhas nos canais sangradouros. No entanto, numa análise do limite praia-duna utilizando-se de fotografias aéreas de alta resolução, observa-se que nem sempre a variação do sistema praia-duna se materializa no limite praia-duna, ficando por vezes restrita a outros segmentos da praia ou das dunas e drenagens. De qualquer maneira variações foram medidas. Estas foram derivadas da ação marinha, do vento e da drenagem pluvial. $\mathrm{O}$ item a seguir visa contribuir com esta análise, analisando séries de dados meteorológicos e oceanográficos.

\subsection{Dados meteo-oceanográficos do período de monitoramento}

A seguir serão apresentados dados meteooceanográficos visando identificar e compreender sua influência na variação da linha de costa (limite praiaduna) apresentada no item anterior.

\subsubsection{Dados meteorológicos}

A figura 10 contempla rosas de vento anteriores a realização dos trabalhos de campo realizados durante o período do monitoramento bem como uma rosa de vento de todo o período (n). Uma rosa de ventos visa demonstrar a intensidade dos ventos e sua direção, definindo porcentagens conforme a variação da intensidade do vento em determinadas direções. Já a série mensal de rosas de vento visa identificar variações num padrão geral de ventos ao longo do monitoramento, o que pode auxiliar na interpretação dos dados apresentados no item anterior.

Os dados da figura 10a, correspondentes ao intervalo do mês anterior ao primeiro trabalho de campo realizado em 15 de junho de 2016, demonstram uma predominância de ventos de WSW e SW, ventos com velocidades majoritariamente inferiores a $10 \mathrm{~m} / \mathrm{s}$. A figura $10 \mathrm{~b}$, que corresponde ao período entre 15 de junho e 8 de julho de 2016, identifica uma predominância de ventos de NE, mas ainda com frequência de ventos de $\mathrm{W}, \mathrm{SW}$ e $\mathrm{S}$. A figura 10c, que correspondente ao período entre 8 de julho e 13 de agosto de 2016, demonstra uma predominância de ventos de WSW e SW, com presença significativa de ventos acima de $12 \mathrm{~m} / \mathrm{s}$ nesta orientação, mas também algumas condições de vento ENE. A figura 10d, que remete ao período entre 13 de agosto e 9 de setembro de 2016, demonstram ventos bastante distribuídos em praticamente todas as direções, com uma leve predominância de ventos do quadrante NE. Todavia também há de se considerar ventos com velocidades superiores a $12 \mathrm{~m} / \mathrm{s}$ provenientes do quadrante SE. A figura $10 \mathrm{e}$, que corresponde ao período de 9 de setembro e 10 de outubro de 2016, demonstra o predomínio de ventos de $\mathrm{E}$, ainda com presença significativa de ventos de SSW. A figura 10f, que demonstra o intervalo de dados entre 10 de outubro e 5 de novembro de 2016 , identificando no período alternância de ventos E e SW. Neste período ocorreu um severo evento erosivo especificamente nos dias 27 a 29 de outubro. No entanto, ao analisarmos os dados das rosas de vento, nesta escala mensal de análise, é difícil perceber a influência dos ventos de SW que atingiram toda a costa do Estado, ficando evidentes na rosa de vento a predominância dos ventos de NE. Porém, ao analisarmos com cautela essa rosa de vento podemos observar ventos superiores a $12 \mathrm{~m} / \mathrm{s}$ de SW. A figura $10 \mathrm{~g}$, que retrata o período entre 5 de novembro e 7 de dezembro de 2016, demonstra a predominância de ventos do quadrante NE. A figura $10 \mathrm{~h}$, correspondente ao intervalo entre 7 de dezembro de 2016 e 12 de janeiro de 2017, também demonstra uma predominância de ventos de NE. A figura 10i nos remete ao intervalo entre 12 de janeiro e 7 de fevereiro de 2017 , mostra o prosseguimento do predomínio de ventos de NE e E, assim como a figura $10 \mathrm{j}$, no intervalo entre $7 \mathrm{de}$ fevereiro e 7 de março de 2017, porém esta identifica também ventos com intensidades superiores a $10 \mathrm{~m} / \mathrm{s}$ de orientação SE. Já a figura 10k nos demonstra a presença massiva de ventos de NE e E, com intensidades superiores a $10 \mathrm{~m} / \mathrm{s}$ entre 7 de março e 5 de abril. Já a figura 101 demonstra ventos bem distribuídos entre NE, W, SSW e W, com predominância de NE e com ventos acima de $10 \mathrm{~m} / \mathrm{s}$ de $\mathrm{W}$ entre 5 de abril e 5 de maio. A figura $10 \mathrm{~m}$ demonstra os dados do período entre 5 de maio e 14 de junho de 2017, onde é possível observar ventos bem distribuídos em todas as direções, ainda com predominância de ventos de NE, e presença de ventos intensos de WSW, SW, SSW, S e SE, característicos da aproximação do inverno. Por fim, a figura 10 n compila os dados de vento durante todo o período analisado, ilustrando claramente o predomínio de ventos do quadrante NE, mas com a presença de ventos com intensidades superiores a $10 \mathrm{~m} / \mathrm{s}$ de direções entre $\mathrm{W}$ e $\mathrm{S}$. 
(a)

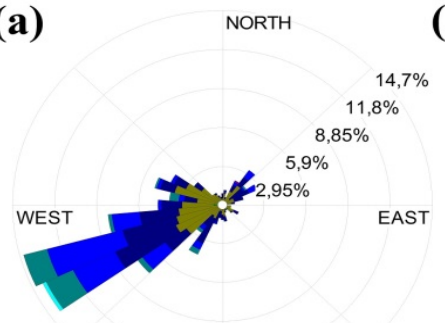

(b)

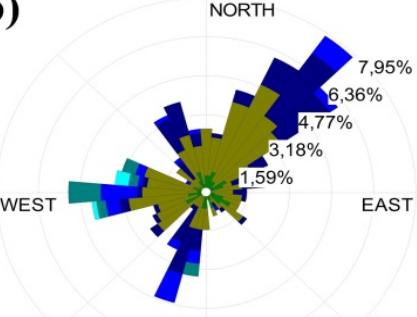

(d)

SOUTH

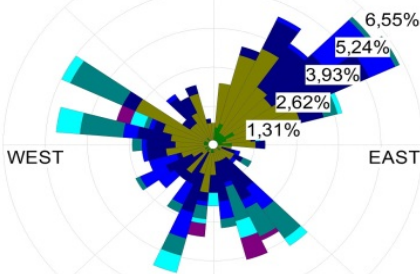

(g)

$$
\text { SOUTH }
$$

NORTH

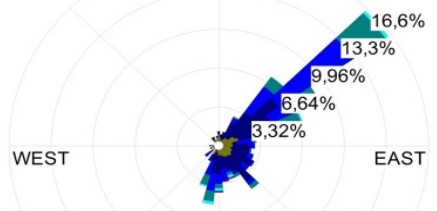

SOUTH

(j)

NORTH

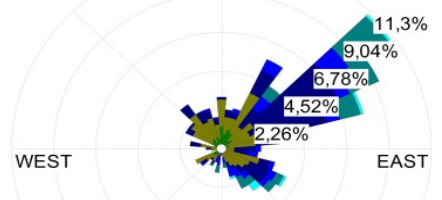

(e)

SOUTH
WEST

(h)

NORTH

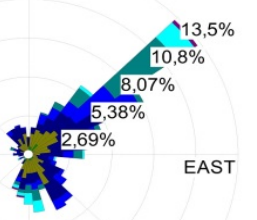

(k)

SOUTH

NORTH (c)

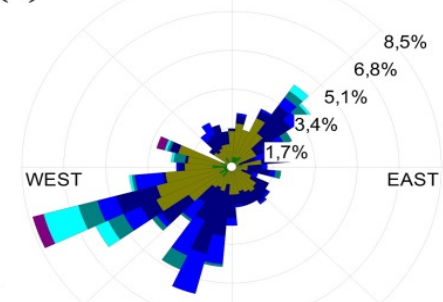

(f)

SOUTH

NORTH
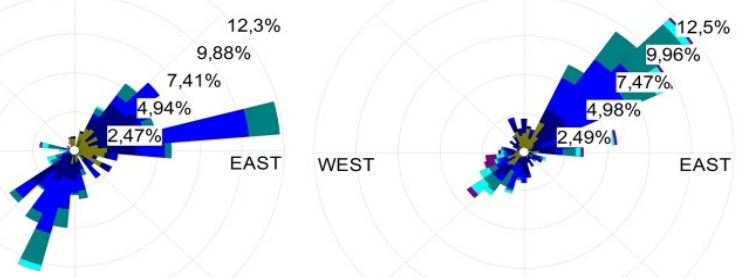

(i)

SOUTH

WEST

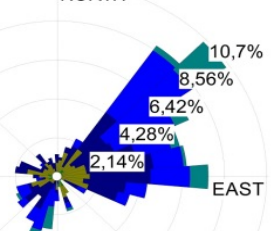

(l)

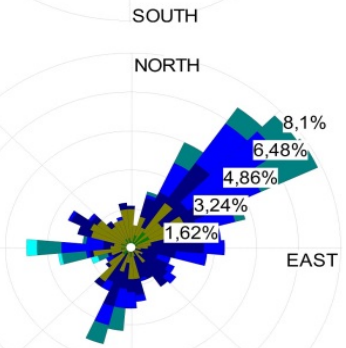

SOUTH

(n)

NORTH

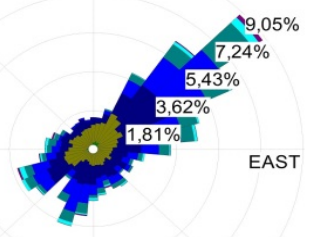

WIND SPEED

$(\mathrm{m} / \mathrm{s})$

$>=12,00$
$10,00-12,00$
$8,00-10,00$
$6,00-8,00$
$4,00-6,00$
$2,00-4,00$
$0,50-2,00$

Figura 10: Rosas de vento nos períodos que antecederam cada um dos trabalhos de campo realizados. (a) 15mai-15jun2016 (b) 15jun-8jul (c)8jul-13ago (d)13ago-9set (e) 9set-10out (f) 10out-5nov2016, (g) 5nov-7dez2016 (h) 7dez-12jan (i) 12jan-7fev (j) 7 fev-7mar (k) 7 mar-5abr (l) 5 abri-5mai2017 (m) 5mai-14jun2017 (n) período total, entre 15jun2016.

Até novembro de 2016 ventos do quadrante sul se mostraram bastante frequentes, mesmo que não predominantes. A partir de novembro os ventos de lestenordeste se intensificaram, até abril de 2017. Em maio e 
junho de 2017 novamente os ventos do quadrante sul se intensificaram na área. Os dados das rosas de vento nos permitem obter um panorama geral da influência dos ventos no limite praia-duna.

Tomazelli (1993) discutiu a sazonalidade do regime de ventos da costa do RS e sua interferência no transporte eólico, fruto das variações na importância relativa dos dois centros de alta pressão que nela atuam, demonstrando redução no potencial de deriva eólica nos meses de outono-inverno inclusive com inversão da deriva de SW para NE. Já na primavera-verão segundo o autor há então o aumento do potencial de deriva eólica com direção resultante para SW, impulsionadas pelos ventos dominantes de NE. No ano monitorado por este trabalho estas condições gerais de inversão da deriva eólica, descritas pelo referido autor, ocorreram na área de estudo. No entanto, condições de alta energia derivadas do vento SW se prolongaram ao longo da primavera de 2016, ao passo que no outono do ano posterior, 2017, condições de ventos NE foram bastante recorrentes.

Martinho (2008) ao analisar dados de vento de toda costa do RS, constatou que em Mostardas é onde há

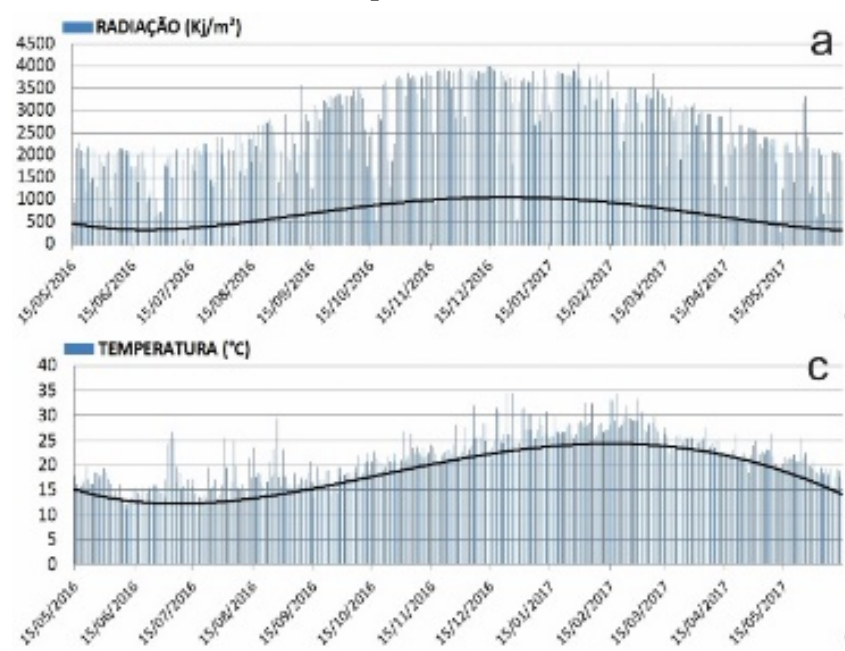

maior energia de ventos na costa do Estado, com menor incidência de calmarias na série analisada. A mesma autora também demonstra a deriva eólica para W e SW no local, podendo ocorrer nestes casos a recomposição da parte superior da praia e base das dunas pela ação eólica, mas também a migração do limite superior da praia em direção ao continente.

A figura 11 mostra dados de radiação solar, temperatura, chuva e umidade instantânea para todo o período de monitoramento. Os dados da figura 11a e 11c nos demonstram o aumento da radiação solar e temperatura entre outubro de 2016 e abril de 2017, quando houve predomínio dos ventos de leste-nordeste. Isto é um fator que pode potencializar o transporte eólico. Todavia, o primeiro semestre de 2017, foi substancialmente mais chuvoso do que o segundo semestre de 2016 na área de estudo, como demonstrado na figura $11 \mathrm{~b}$, fato que pode ter prejudicado um pouco o transporte eólico nesse período. Mesmo assim o transporte eólico teve sua relevância, dada a ação dos ventos de $\mathrm{E}$ e NE.

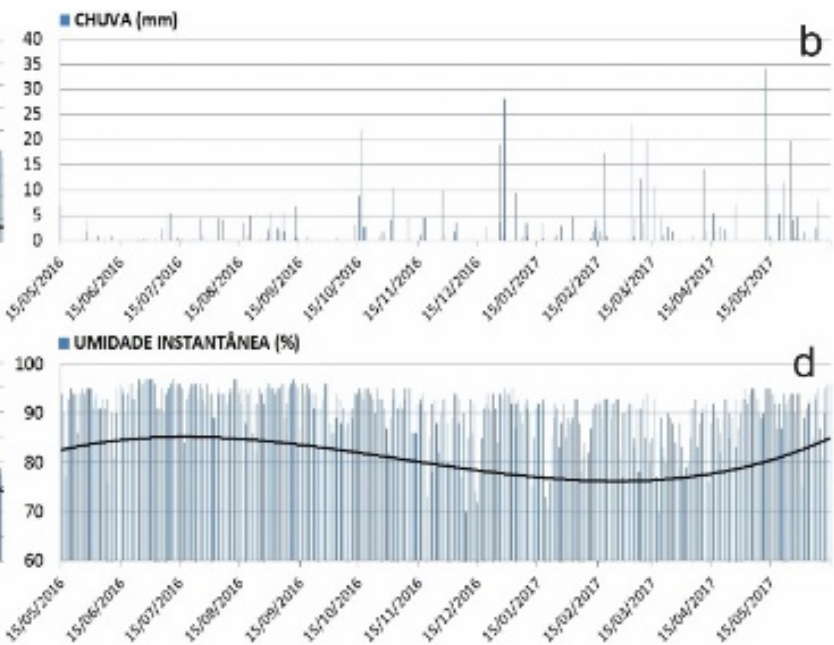

Figura 11: (a) Radiação $\left(\mathrm{Kj} / \mathrm{m}^{2}\right)$ e sua linha de tendência entre 15/5/2016 e 14/6/2017. (b) Chuva (mm) entre 15/5/2016 e 14/6/2017. (c) Temperatura $\left({ }^{\circ} \mathrm{C}\right)$ e sua linha de tendência no mesmo período. (d) Umidade instantânea no momento da coleta e sua linha de tendência no mesmo período.

\subsubsection{Dados oceanográficos}

Os dados oceanográficos a seguir apresentados referem-se aos obtidos por dois ondógrafos situados na costa do Rio Grande do Sul (figuras 12, 13, 14 e 15), onde foram extraídos dados de altura, período e direção de onda.

As figuras 12 e 13 demostram os dados de onda analisados entre maio de 2016 e o início de janeiro de 2017 nos dois ondógrafos: PNBOIA e Rede Ondas respectivamente. Antes do primeiro trabalho de campo, ocorreram pelo menos dois eventos de alta energia de onda, provenientes do quadrante sul. Entre os trabalhos de campo de junho e julho não ocorreram eventos significativos de alta energia. Já entre julho e agosto, ocorreram outros dois eventos de alta energia de onda. Entre agosto e outubro pelo menos mais três eventos de alta energia ocorreram na área de estudo, indicando um período bastante energético no clima de ondas local. No entanto, o destaque do período de 2016 em relação à incidência de ondas ficou por conta do evento extremo de alta energia ocorrido em outubro de 2016, destacado na figura 12, que será descrito a seguir. Posteriormente, houve uma interrupção da série de dados, mas segundo observações in loco ainda houve mais um evento de alta energia de ondas no início de dezembro de 2016. As figuras 12 e 13 remetem a um período de ocorrência de vários eventos de alta energia de onda na costa, sendo identificados pelo menos 8 nos gráficos, podendo ainda ser 9 se considerarmos o evento ocorrido num período sem informação coletada (dezembro 2016). Estes dados provavelmente foram relevantes nas taxas de variação da linha de costa no período, onde predominaram dados erosivos em relação aos acrescivos, conforme descrito no item anterior. Houve alguma recomposição entre agosto e setembro provavelmente por conta da maior ação eólica em relação ao impacto das ondas, mas no geral a ação das ondas foi mais significativa no que 
tange as taxas de variação da linha de costa, mesmo que os dados de vento local tenham também sua relevância.

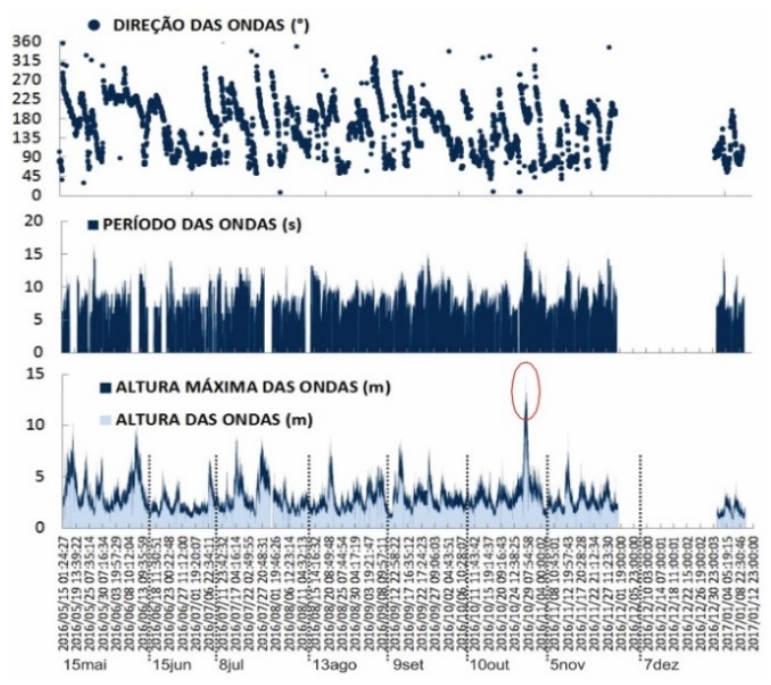

Figura 12: Dados PNBOIA referentes ao primeiro semestre do monitoramento. Destaque para alturas superiores a $9 \mathrm{~m}$ durante o ciclone de outubro de 2016.

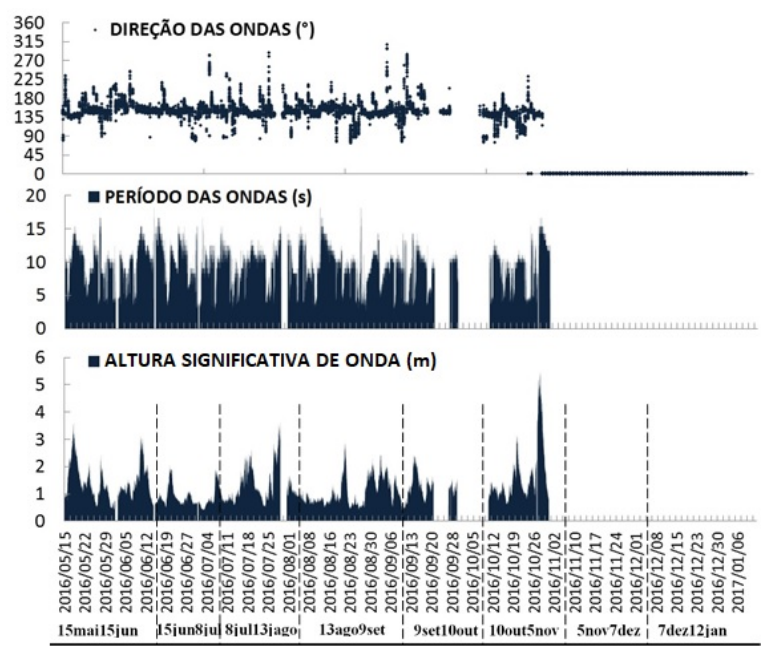

Figura 13: Dados Rede Ondas referentes ao primeiro semestre do monitoramento. Destaque para o ciclone de outubro de 2016.

Durante os dias de 27 a 29 de outubro de 2016, sopraram ventos de SSW com rajadas superiores aos 27 $\mathrm{m} / \mathrm{s}(\sim 100 \mathrm{~km} / \mathrm{h})$, gerando ondas com as maiores alturas do período do monitoramento, como pode ser observado nas figuras 12,13 e 14 .

A figura 14 demonstra um recorte temporal com compilação dos dados dos dois ondógrafos e do marégrafo do porto do Rio Grande, entre os dias 24 e 31 de outubro, ilustrando melhor a magnitude do evento que ocorreu entre 27 e 29 de outubro de 2016. Este mesmo evento caracterizado aqui especificamente para o balneário Mostardense, foi também caracterizado por Albuquerque et al. (2018) no balneário Hermenegildo, no extremo Sul da costa do Estado, também com valores elevados de recuo de linha de costa e perda de patrimônio edificado. Também analisando este evento extremo, Oliveira et al. (2019) realizaram uma comparação da linha de costa antes e depois do referido evento em 6 áreas urbanizadas do litoral do Estado, sendo os maiores valores encontrados nos balneários Praia do Farol e Mostardense respectivamente.

$\mathrm{O}$ auge do evento ocorreu na madrugada do dia 28 de outubro, onde as ondas apresentaram altura significativa de mais de $9 \mathrm{~m}$ no ondógrafo situado no segmento oceânico defrontante a Mostardas, chegando até $14 \mathrm{~m}$ de altura máxima, sendo que no situado em águas mais rasas, a altura significativa das ondas passou dos $5 \mathrm{~m}$. É possível ainda observar, que ocorreu uma sutil mudança na direção das ondas a partir do início da tarde do dia 27, o que propiciou que as ondas que já estavam aumentando em altura com direção $\mathrm{SW}$, passassem a incidir na costa na direção S. O período foi de cerca de 15 segundos e permaneceu alto por vários dias (figura 14).

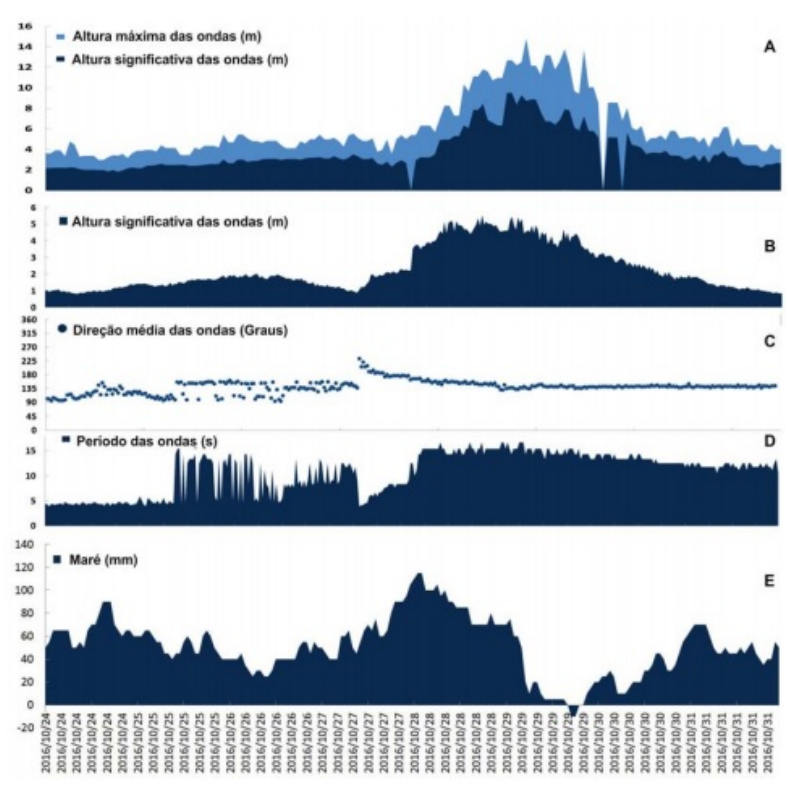

Figura 14: Gráficos de parâmetros hidrodinâmicos costeiros entre 24/10/2016 e 31/10/2016 destacando o momento relevante para a erosão da costa (a) Altura máxima e significativa das ondas medidas pelo ondógrafo do PNBOIA, localizado no segmento oceânico defrontante ao balneário Mostardense, a $100 \mathrm{~km}$ da costa; (b, c, d) Altura significativa, direção média e período das ondas medidas pelo ondógrafo do Rede Ondas, localizado ao largo do balneário Cassino; (e) Maré, em milímetros, medida pela Praticagem do Porto do Rio Grande no canal de acesso ao Porto (Fonte: Oliveira et al. 2019).

Por sua vez, a figura 15 demonstra dados de onda para o período de 2017 analisado neste trabalho. Esta serie não identifica a mesma quantidade de eventos de alta energia de ondas que o anterior. 


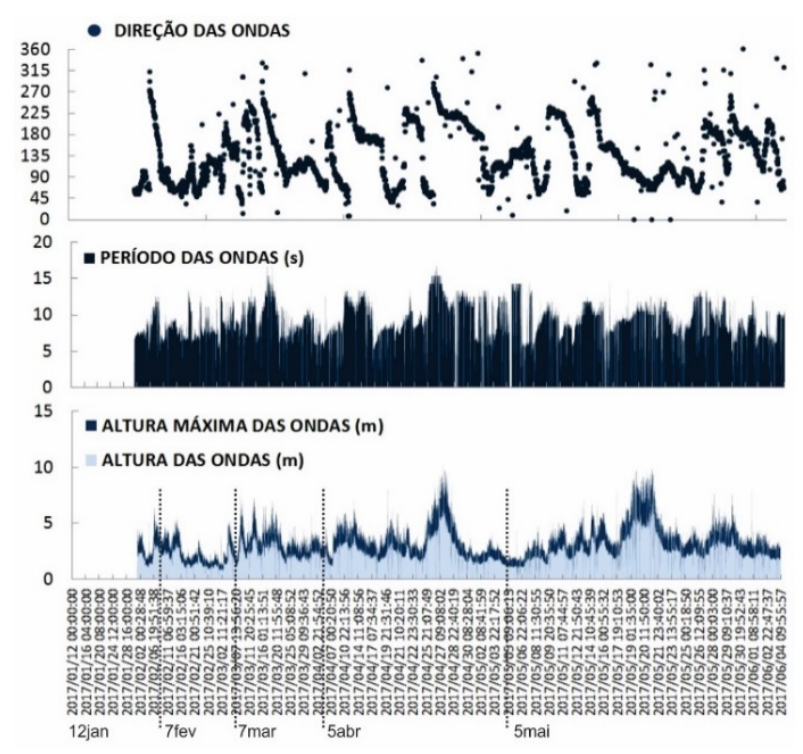

Figura 15: Direção, período e altura das ondas durante o segundo semestre do monitoramento com VANT obtidas pelo ondógrafo PNBOIA.

No verão e início do outono, sobretudo até o mês de abril de 2017, a praia se manteve relativamente estável (figuras 7 e 8), podendo isto ter influência da ação eólica local e pelo predomínio de ventos e ondas de NE e E (figura 15). Porém, ao final deste intervalo observa-se ondas de alta energia, com alturas próximas aos $5 \mathrm{~m}$ de orientação SSE. De qualquer forma, neste período o limite praia-duna permaneceu estável. Entre março e abril, os dados de onda demonstraram um evento de alta energia de ondas virando de SW para $\mathrm{S}$, com períodos superiores a $15 \mathrm{~s}$ e alturas na casa dos $5 \mathrm{~m}$ no início da série. Na sequência os mesmos demonstraram a predominância de ondas de E e SE de menor energia, fato que, em conjunto com a ação eólica local, podem ter influenciado na recomposição do limite praia-duna identificado. Entre abril e maio houve acreção, fato que pode ser explicado pelo período de baixa energia de onda ocorrido antes do levantamento. Na figura 15, é possível perceber que neste intervalo o evento com maior energia de ondas teve proveniência de NE, direção de onda que habitualmente não causa retração das dunas frontais no RS em função das marés mais baixas geradas. Já entre maio e junho houve erosão, provavelmente tendo influência da alta energia ocorrida no período anterior ao último trabalho de campo ou a maior energia de onda logo antes do período medido se comparado ao que ocorreu no mês anterior, onde a medição ocorreu após dias de baixa energia de onda. A análise dos dados de onda revelou que neste período, foram identificados pelo menos 4 eventos com ondas de $\mathrm{S}$ e alturas médias entre 3 e $5 \mathrm{~m}$ que poderiam ter auxiliado no processo de retração de linha de costa medido.

\subsection{Processos costeiros atuantes na variação do limite praia-duna}

Nos itens anteriores, ao analisarmos os dados derivados das fotografias aéreas obtidas pelo VANT, foi possível quantificar com alta precisão os valores de variação da linha de costa (limite praia-duna) bem como identificar a ação eólica e das ondas nas próprias imagens obtidas mensalmente. Por sua vez, os dados meteo-oceanográficos auxiliaram para compreender melhor os processos de recomposição das dunas frontais por ação eólica, geralmente ocasionados por períodos de intensidade de ventos provenientes do quadrante $\mathrm{NE}$ e pouca precipitação, somados a considerada radiação solar, o que facilita o movimento das dunas (Tomazelli 1993). Também inferir sobre condicionantes com potencial para causar erosão costeira, uma vez que estes processos geralmente estão associados a passagem de frentes frias e ciclones com fortes ventos de SSW, que propiciam a incidência de ondas de alta energia que erodem a praia (Calliari \& Toldo Jr. 2016).

Segundo Short \& Hesp (1982), durante períodos erosivos, tempestades costeiras podem causar a fragmentação da duna e a morte de parte da vegetação que fixa a duna frontal, além de escarpar a mesma, permitindo que a ação eólica posterior, dependendo de sua orientação e energia, possa remobilizar os sedimentos em direção ao continente e reativar dunas que estavam relativamente estabilizadas. Isto pôde ser verificado já nos primeiros períodos de medição na área de estudo, marcado pela alta energia de onda. No primeiro trabalho de campo realizado, as dunas apresentavam-se bastante escarpadas, com escarpas com alturas em torno dos $4 \mathrm{~m}$ em alguns segmentos e presença de turfas no pós-praia, tendo influência dos eventos de alta energia de onda ocorridos anteriormente ao período monitorado. Estes processos erosivos (figura 16a) são muitas vezes intercalados com períodos de recomposição, como mostra a figura $16 \mathrm{~b}$.

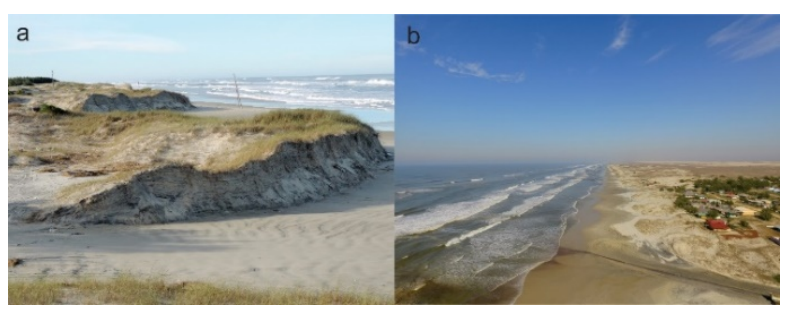

Figura 16: (a) Escarpas nas dunas frontais do balneário Mostardense em 8 de julho de 2016. (b) Aporte eólico na base das dunas frontais em 13 de agosto de 2016.

Durante o monitoramento do limite praia-duna, observou-se que o principal agente erosivo das dunas foram as ondas, sobretudo quando elas atingem o limite superior da praia. No evento extremo de 2016, por exemplo, as ondas ultrapassaram em muitos locais as dunas frontais. As fotografias da figura 17 mostram a ação das ondas na área de estudo nesse evento.

Estas fotografias coletadas por moradores locais demonstram a elevação do nível do mar ocasionada pelo evento, além da elevada energia de onda, com capacidade para remover segmentos de dunas frontais, expondo arbustos e suas raízes à dinâmica marinha direta. Os efeitos deste evento causaram alteração significativa no traçado da linha de costa como ilustrado nas figuras 4, 6, 8, 9, 17 e 18 . 


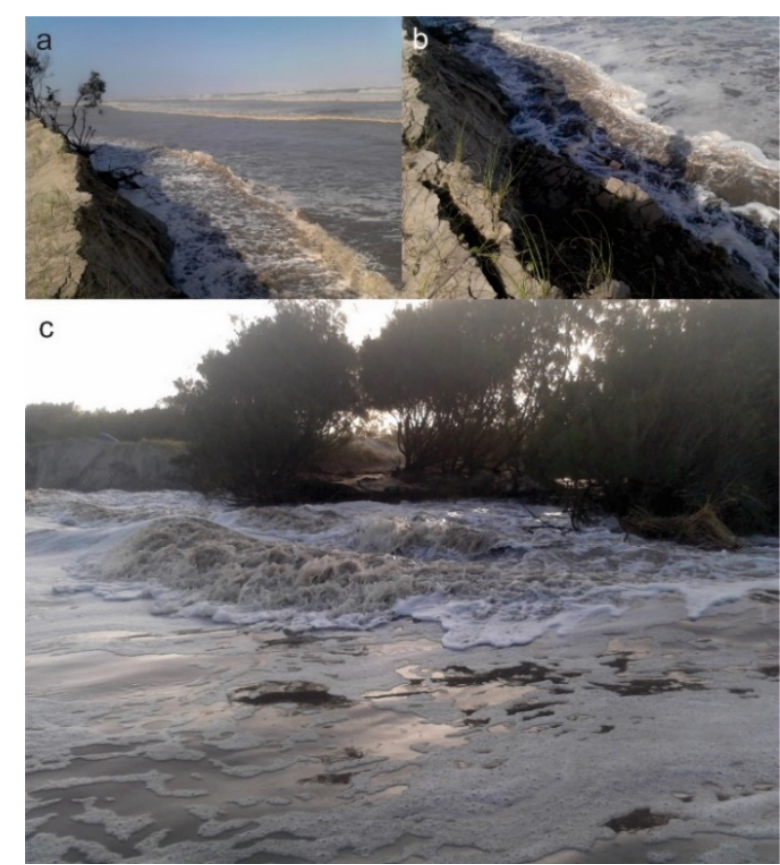

Figura 17: Fotografias realizadas ao final da tarde do dia 28/10/2016 por morador local, demonstrando a maré meteorológica e ondas de alta energia chegando a base das dunas frontais. (a) Arbustos expostos a ação marinha direta. (b) Ondas solapando a base da duna frontal. (c) Inundação na proximidade de um canal sangradouro.

A figura 18 mostra que edificações que outrora estavam no revesso das dunas frontais atualmente estão diretamente expostas a ação direta das ondas.

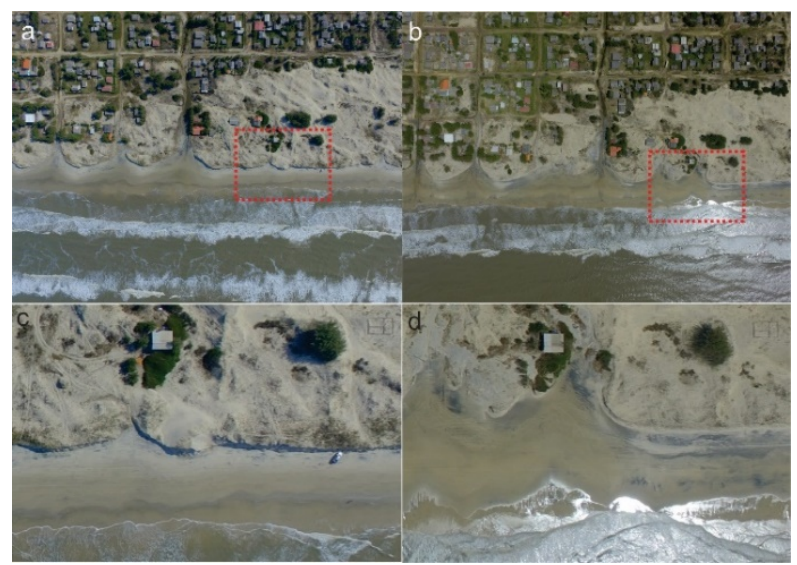

Figura 18: (a) Fotografia vertical realizada em 15 de junho de 2016 com destaque (c) para ocupação e para as dunas frontais. (b) Fotografia vertical realizada em 5 de novembro de 2016 com destaque (d) para a mesma ocupação e para o processo erosivo que removeu grande parte das dunas frontais, expondo a vegetação da frente da ocupação diretamente a ação marinha.

Com a diminuição da energia de ondas após o evento extremo de alta energia de ondas, os sedimentos retornaram a praia subaérea, repetindo a recomposição descrita na figura $16 \mathrm{~b}$, embora o saldo negativo, causado pela erosão, tenha sido muito superior.

A fotografia oblíqua (figura 19a) revela a presença de aporte eólico na base das dunas frontais e a presença de cúspides praiais. Já a figura 19b, demonstra uma berma de acreção formada no momento menos energético do intervalo de monitoramento. $\mathrm{Na}$ imagem destaca-se a presença de minerais pesados no pós-praia e base das dunas frontais, resquícios do período de alta energia anterior.

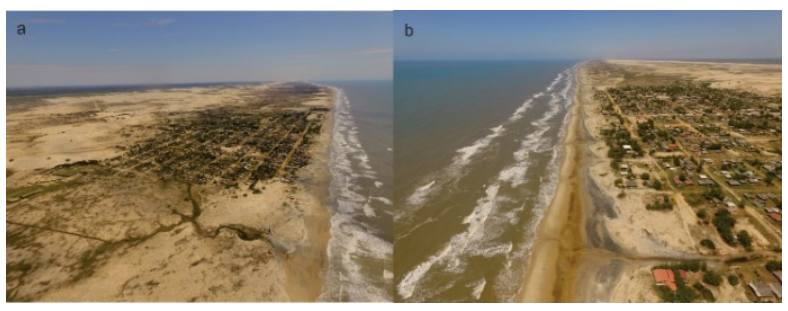

Figura 19: (a) Fotografia oblíqua do balneário Mostardense em 7 de dezembro de 2016 obtida a partir de um VANT. (b) Berma de acreção em contraste com presença massiva de minerais pesados no balneário Mostardense em 12 de janeiro de 2017.

No ano de 2017, o limite praia-duna sofreu mais ação eólica, que pode ter atuado tanto na acreção como também na erosão do limite praia-duna analisado. $\mathrm{Na}$ base das dunas frontais é frequente a deposição de sedimentos por ação eólica, como identifica a figura 20a. No entanto, como esta área tem um comportamento geomorfológico da barreira tendendo a retrogradação, isto é, migrando em direção continental, os processos eólicos também causam a migração das dunas em direção ao interior continental. É possível identificar ocupações em processo de soterramento muito próximas a linha de costa (Simões 2015). Isto remete a um transporte eólico significativo, que, com a erosão da base e perda de vegetação das dunas, os sedimentos são deslocados em direção à ocupação costeira (figura 20b).

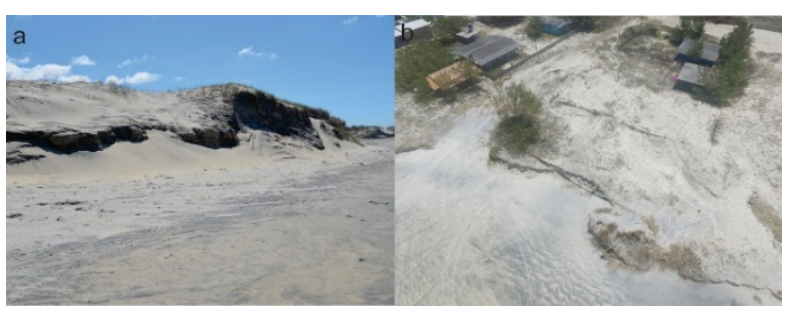

Figura 20: (a) Recomposição das dunas frontais em 9 de setembro de 2016 no balneário Mostardense. (b) Erosão das dunas frontais e transgressão eólica em outubro de 2016 no balneário Mostardense com destaque para o alicerce de uma ocupação aflorando no limite praiaduna.

O processo erosivo que vem ocorrendo, pelo menos desde 2005 no balneário Mostardense, está suprimindo as dunas frontais entre o pós-praia e a ocupação, estas deslocam-se impulsionadas pelo vento predominante de NE, e em função da orientação da linha de costa acabam por migrar sobre as ocupações ocasionando problemas relacionados ao soterramento de edificações, fatos já evidenciados em trabalhos anteriores.

\section{Considerações finais}

Ao término desse monitoramento, após um ano de acompanhamento, totalizando 13 trabalhos em campo para coleta de dados com VANT em conjunto com o uso de receptor geodésico e o levantamento e tratamento de dados meteo-oceanográficos, foi possível demonstrar a não linearidade do comportamento da linha de costa junto ao balneário Mostardense frente às variáveis meteo-oceanográficas avaliadas. 
Apesar de uma aparente estabilidade durante o período do monitoramento, salienta-se que um único evento hidrodinâmico extremo foi capaz de retrair a linha de costa cerca de 13,8 m em média. Todavia, em alguns segmentos específicos esse recuo foi superior a $40 \mathrm{~m}$ (figura 18), ameaçando diretamente as ocupações que outrora estavam no revesso das dunas frontais, e atualmente estão diretamente expostas a ação direta das ondas. Estas ocupações podem acabar sendo destruídas por eventos de alta energia de onda futuros.

Fortes ventos soprando de $\mathrm{S}$ e SW, por longos segmentos oceânicos, criam as condições oceanográficas mais energéticas que podem ocasionar acentuada erosão costeira, em intervalos de apenas um ou dois dias. Todavia, mesmo tendo-se mais ventos de $\mathrm{S}$, durante o inverno e onde consequentemente se esperaria um processo erosivo mais acentuado, o período onde ocorreu a maior retração da linha de costa foi na primavera, onda havia predominância de ventos de NE. Já ventos e ondas do quadrante E tendem a gerar ondas com menor poder de ação sobre o limite superior da praia no local além de potencializar os processos eólicos.

Dessa forma, os processos costeiros que atuam no limite praia-duna na área de estudo são as ondas durante períodos de alta energia, onde atingem a base das dunas e em eventos extremos podem ainda transpor as dunas frontais (overwash), além da ação do vento que desloca as areias da face da praia para as dunas ou das dunas para a base. $\mathrm{Na}$ área de estudo, com base em trabalhos anteriores, podemos destacar que tanto a ação marinha quanto a eólica tende a deslocar o sistema praia duna para o interior continental, sendo a ação eólica não somente acresciva, mas também podendo transportar os sedimentos eólicos deste local, causando em conjunto o predomínio da erosão neste segmento.

Os resultados obtidos também apontam para as potencialidades da utilização da ferramenta VANT em estudos de morfodinâmica costeira, podendo ser utilizado tanto para análises qualitativas (fotografias oblíquas) como para análises quantitativas (fotografias verticais).

\section{Agradecimentos}

A CAPES e ao Programa de Pós-Graduação em Geografia - PPGGeo da Universidade Federal do Rio Grande - FURG, pela bolsa de mestrado do primeiro autor. Ao CNPq pelo edital que possibilitou a compra do VANT utilizado e diárias de campo e aos Grupos de Pesquisa GEOMA-IFRS e LACRIO-FURG pelo auxílio em determinadas etapas do tratamento dos dados e empréstimo de softwares e equipamentos. A Monique Macedo, João Simões, Jean Espinoza, Miguel Albuquerque, Paulo Salati de Souza e Christian Enriquez pelo auxílio nas coletas de dados em campo.

\section{Referências}

Absalonsen L., Toldo Jr. E. 2007. A Influência da Inflexão Costeira na Variabilidade da Linha de Praia em Mostardas - RS. Porto Alegre: Revista Pesquisas em Geociências. 34:3-18.
Albuquerque M.G. 2013. Análise espaço-temporal das causas da variabilidade da linha de costa e erosão na praia do Hermenegildo - RS. Tese de doutorado, Instituto de Geociências, Universidade Federal do Rio Grande do Sul, Porto Alegre - RS. 127 p.

Albuquerque M.G., Espinoza J.M.A., Oliveira A., Corrêa I., Calliari L.J. 2013. Erosion or Coastal Variability: an evaluation of the DSAS and the Change Polygon methods for the determination of erosive processes on sandy beaches. Florida: Journal of Coastal Research. Special Issue 65:1710-1714.

Albuquerque M. G., Espinoza J. M. A., Alves D.C.L., Oliveira U.R., Simões R.S. 2018. Determining Shoreline Response to Meteooceanographic Events Using Remote Sensing and Unmanned Aerial Vehicle (UAV): Case Study in Southern Brazil. Journal of Coastal Research, SI 85: 766-770.

Almeida L.E.S.B., Rosauro N.M.L., Toldo Jr. E.E. 1997. Análise Preliminar das Marés na Barra do Rio Tramandaí. $12^{\circ}$ Simpósio Brasileiro de Recursos Hídricos, Vitoria: p. 560 - 566.

Barletta R.C. 2000. Efeito da interação oceano-atmosfera sobre a morfodinâmica das praias do litoral central do Rio Grande do Rio Grande do Sul, Brasil. Dissertação de Mestrado, Programa de PósGraduação em Oceanografia Física, Química e Geológica. Universidade Federal Rio Grande, Rio Grande, $134 \mathrm{p}$.

Barletta R.C. 2006. Teste e aplicação de modelos parabólicos de refração-difração com ênfase na propagação de ondas sobre parcéis. Tese de doutorado, Programa de Pós-Graduação em Engenharia Ambiental, Universidade Federal de Santa Catarina, Florianópolis - SC, $155 \mathrm{p}$.

Bird E. 2008. Coastal Geomorphology - An Introduction. England: Wiley, $436 \mathrm{pg}$.

Calliari L.R., Muehe D., Hoefel F.G., Toldo Jr. E. 2003. Morfodinâmica praial: uma breve revisão. São Paulo: Revista Brasileira de Oceanografia. 51:53-68.

Calliari L.R., Pereira P.S., De Oliveira A.O., Figueiredo S.A. 2005. Variabilidade das Dunas Frontais no Litoral Norte e Médio do Rio Grande do Sul, Brasil. Porto Alegre: GRAVEL. 3:15-30.

Calliari L.J., Toldo Jr E.E. 2016. Chapter 18 - Ocean Beaches of Rio Grande do Sul. In: Short A.D., Klein A.H.F. (org.) Brazilian Beach Systems. Florida: Springer, p. 1-36.

Davies J.L. 1964. A morphologic approach to the word's shorelines. Geomorphology. 8:127-142.

Dillenburg S.R.,Tomazelli L.J., Martins L.R., Barboza E.G. 2005 Modificações de Longo Período da Linha de Costa das Barreiras Costeiras do Rio Grande do Sul. Porto Alegre: GRAVEL. 3: 9-14.

Dillenburg S.R., Barboza E.G., Tomazelli L.J., Hesp P.A., Clerot L.C.P., Ayup-Zouain R.N. 2009. Chapter 3 - The Holocene Coastal Barriers of Rio Grande do Sul. In: Dillenburg, S.R.; Hesp, P.A. (Ed). Springer. Geology and Geomorphology of Holocene Coastal Barriers of Brazil. Berlim: Springer, p. 53-91.

Disperatti A.A. 1995. Fotografias aéreas inclinadas. Curitiba: Editora UFPR. 113 p.

Esteves L.S. 2006. Rio Grande do Sul. In: Muehe D. (Org.) Erosão e Progradação do Litoral Brasileiro. Ministério do Meio Ambiente, p. 460-467.

Dolan R., Davis R.E. 1992. An intensity scale for Atlantic coast northeast storms. Journal of Coastal Researsh. 8(3):840-853.

Jensen J.R. 2009. Sensoriamento Remoto do Ambiente: uma perspectiva em recursos terrestres. Tradução de J.C.N. Epiphanio. São José dos Campos: Parênteses. 598 p.

Klein A.H.F., Short A.D. 2016. Brazilian Beach Systems: Introduction. In: Short A.D., Klein A.H.F. (Org.) Brazilian Beach Systems. Springer: Florida, p. 1-36.

Leal K.B. 2016. Análise da variação da linha de costa nos balneários Mostardense, Mar Grosso, Cassino e Barra do Chuí - RS a partir de geotecnologias. Trabalho de conclusão de curso em Geografia. FURG. 90 p

Leal K.B., Oliveira U.R., Espinoza J.M.A. 2018. Variação do limite praia-duna nos Balneários Mostardense, Mar Grosso, Cassino e Barra do Chuí - RS no intervalo entre 2003-2015. Quaternary and Environmental Geosciences, 9: 25-37.

Lima S.F., Almeida L.E.S.B., Toldo Jr. E.E. 2001. Estimate of longshore sediments transport from waves data to the Rio Grande do Sul coast. Porto Alegre: Pesquisas em Geociências. 48: 99-107.

Martinho C.T. 2008. Morfodinâmica e evolução de campos de dunas transgressivos quaternários do litoral do Rio Grande do Sul. Tese de doutorado em Geociências. Universidade Federal do Rio Grande do Sul - UFRGS. Porto Alegre. 241 p. 
Nicolodi J.L., Toldo Jr E.E., Almeida L.E.S.B. 2003. Correntes costeiras induzidas por eventos de tempestades no litoral médio do Rio Grande Do Sul. Anais do IX Congresso Brasileiro de Estudos do Quaternário.

Oliveira U.R., Leal K.B., Simões R.S., Rodrigues G., Porto F., Moreira J. 2015. Geomorfologia costeira junto aos balneários oceânicos do litoral médio e sul do estado do Rio Grande do Sul: uma abordagem qualitativa. Imbé-RS: Anais da associação Brasileira de Estudos do Quaternário - ABEQUA. p. 56-57.

Oliveira U.R., Simões R.S., Calliari L.J., Gauterio B.C. 2019. Erosão de dunas sob ação de um evento extremo de alta energia de ondas na costa central e Sul do Rio Grande do Sul, Brasil. Revista Brasileira de Geomorfologia, 20:137-158.

Pereira P.S., Calliari L.J., Barletta R.C. 2010. Heterogeneity and homogeneity of Southern Brazilian beaches: A morphodynamic and statistical approach. Continental Shelf Research, 30:270-280.

Scottá F.C., Rockett G.C., Portz L., Cardia V.C. 2015. Deslocamento de dunas costeiras: uma análise através de dados de sensoriamento remoto orbital na Lagoa do Peixe, RS. Porto Alegre: Gravel, 13(1):15-25

Short A.D., Hesp P. 1982. Wave, beach and dune interactions in southeastern Australia. Amsterdan: Marine Geology, 48:259-284.

Short A.D. 1999. Handbook of Beach and Shoreface Morphodynamics. Chichester, England: Wiley, 379 p.

Simões R.S. 2015. Análise da distância média entre as ocupações a beira-mar e o limite superior da praia nos balneários São Simão, Mostardense, Praia do Farol e Mar Grosso, RS. Trabalho de Conclusão de Curso em Geografia. Universidade Federal do Rio Grande - FURG, 84 p.

Simões R.S., Oliveira U.R., Espinoza J.M.A. 2017. Balneário Mostardense - RS: da transgressão eólica sobre edificações à erosão costeira. Anais do Encontro Nacional de Gerenciamento Costeiro - ENCOGERCO p. 261-262.

Recebido 30 de setembro de 2019 Aceito 10 de fevereiro de 2020
Simões R.S., Oliveira U.R. 2017. Análise da variação do limite superior da praia no balneário Mostardense, com auxílio de diferentes geotecnologias. In: Anais do XVI Congresso da Associação Brasileira de Estudos do Quaternário - ABEQUA Mudanças Climáticas no Passado e no Presente: Conhecer para Entender as Consequências no Futuro, Bertioga - SP.

Simões R.S. 2018. Mobilidade do limite praia-duna no balneário Mostardense - RS: monitoramento por VANT. Dissertação de Mestrado, Programa de Pós-Graduação em Geografia, Universidade Federal do Rio Grande. 128p

Simões R.S., Oliveira U.R., Espinoza J.M.A., Albuquerque M.G., Alves D.C.L. 2019. Uso de drone de pequeno porte para análise costeira: enfoque metodológico. Revista Brasileira de Geografia Física, 12(2):622-640.

Smith M.J., Cromley R.G. 2012. Measuring historical coastal change using GIS and the change polygon approach. Transactions in GIS. 16:3-15.

Toldo Jr. E.E., Almeida L.E.S.B., Nicolodi J.L., Martins L.R. 2006. Rio Grande do Sul. In: Muehe D. (Org.) Erosão e Progradação do Litoral Brasileiro. Ministério do Meio Ambiente, p. 468-475.

Tomazelli L. 1993. O Regime dos Ventos e a Taxa de Migração das Dunas Eólicas Costeiras do Rio Grande do Sul, Brasil. Pesquisas em Geociências, 20 (1): 18-26.

Tomazelli L.J., Villwock J.A. 2000. O Cenozoico no Rio Grande do Sul: Geologia da Planície Costeira. In: Holz M., De Ros L.F. (Eds.). Geologia do Rio Grande do Sul. Porto Alegre: CIGO/UFRGS, p. 375-406.

Tomazelli L.J., Villwock J.A. 2005. Mapeamento Geológico de Planícies Costeiras: o Exemplo da Costa do Rio Grande do Sul. Porto Alegre: Gravel. 3:109-115.

Villwock J.A., Tomazelli L.J. 1995. Geologia Costeira do Rio Grande do Sul. Porto Alegre: Notas Técnicas/Centro de Estudos de Geologia Costeira e Oceânica. Universidade Federal do Rio Grande do Sul - CECO/IG/UFRGS, 8:1-45. 